\title{
Techniques of Preparation of Thin Films: Catalytic Combustion
}

\author{
Marius Stoian ${ }^{1} \mathbb{D}$, Thomas Maurer ${ }^{2} \mathbb{D}$, Salim Lamri ${ }^{3}$ and Ioana Fechete $4,5, *$ \\ 1 Laboratory of Chemical Technology and Catalysis, Department of Organic Chemistry, \\ Biochemistry and Catalysis, Faculty of Chemistry, University of Bucharest, 4-12, Blv. Regina Elisabeta, \\ 030018 Bucharest, Romania; marius_stoian7@yahoo.ro \\ 2 Laboratoire Lumière, Nanomatériaux \& Nanotechnologies (L2n), Université de Technologie de Troyes \& \\ CNRS ERL 7004, 12 Rue Marie Curie, 10000 Troyes, France; thomas.maurer@utt.fr \\ 3 LISI-Aerospace, 52000 Chaumont, France; salim.lamri@lisi-group.com \\ 4 ICD-LASMIS, Université de Technologie de Troyes, Antenne de Nogent, Pôle Technologique de Sud Champagne, \\ 52800 Nogent, France \\ 5 Nogent International Center for CVD Innovation-NICCI, LRC-CEA-ICD-LASMIS, \\ Université de Troyes-Antenne de Nogent, Pôle Technologique Sud Champagne, 26, Rue Lavoisier, \\ 52800 Nogent, France \\ * Correspondence: i_fechete@yahoo.com
}

\section{check for}

updates

Citation: Stoian, M.; Maurer, T.; Lamri, S.; Fechete, I. Techniques of Preparation of Thin Films: Catalytic Combustion. Catalysts 2021, 11, 1530. https://doi.org/10.3390/catal11121530

Academic Editor: Vincenzo Palma

Received: 19 September 2021

Accepted: 29 November 2021

Published: 15 December 2021

Publisher's Note: MDPI stays neutral with regard to jurisdictional claims in published maps and institutional affiliations.

Copyright: (C) 2021 by the authors. Licensee MDPI, Basel, Switzerland. This article is an open access article distributed under the terms and conditions of the Creative Commons Attribution (CC BY) license (https:// creativecommons.org/licenses/by/ $4.0 /)$.

\begin{abstract}
Over the past several decades, an increasing amount of attention has been given to catalytic combustion as an environmentally friendly process. However, major impediments to large-scale application still arise on the materials side. Here, we review catalytic combustion on thin film catalysts in view of highlighting some interesting features. Catalytic films open the way for new designs of structured catalysts and the construction of catalysts for catalytic combustion. A special place is occupied by materials in the form of very thin films that reveal catalytic activity for various chemical reactions. In this review, we demonstrate the high catalytic activity of thin film catalysts in these oxidation reactions.
\end{abstract}

Keywords: methane; carbon monoxide; total oxidation; thin film catalysts; environment

\section{Introduction}

Catalytic combustion represents a viable approach to obtain energy from fuels and to control emissions released into the atmosphere from different industrial processes. Catalytic total oxidation effectively minimizes emissions of methane, carbon monoxide and volatile organic compounds (VOCs) in industrial gases [1,2]. Comprising mostly harmful gases such as methane, carbon monoxide, or volatile organic compounds (VOCs), which include benzene, toluene, formaldehyde, and chlorinated compounds, these continuous emissions have a hazardous impact on the ecosystem and all its inhabiting organisms, since most of them contribute to the global warming effect, alongside to the increasing toxicity of the environment. However, various catalysts are able to remove these harmful compounds by oxidation reaction, most noteworthy among them containing noble metals (e.g., $\mathrm{Pd}, \mathrm{Pt}$ ) or transition metal oxides [3-6].

Nevertheless, extended use of catalysts in combustion conditions can bring stability issues with severe deactivation due to sintering of catalyst particles at a high operating temperature [7]. In order to reduce the deactivation process, there is an increased interest in low-temperature operating catalysts for methane oxidation, as methane is the usual standard to assess the combustion activity properties for its high stability, as well as for its notable pollutant characteristics [8].

Multiple techniques employed in material preparation aim to obtain more active catalysts in oxidation reaction by increasing the available surface area, the redox properties or by including different species to yield a composite material with enhanced activity. Growth of active materials in thin film form can produce impressive results regarding 
the combustion activity of the catalysts and their stability depending on the choice of composite components.

Thin films deposition provides an attractive method which allows more control over the size and thickness of the grown material with considerable effects on the catalytic activity, over the interactions between the layers of the composite which influence the redox capabilities. In this context, we aim to provide insights in this paper on the use of thin film technology in the preparation of active catalysts for combustion of methane and carbon monoxide.

\section{History of Thin Films}

Thin film technology is one of the oldest arts, dating back to the metal ages of antiquity, and is one of the newest sciences. Thin film technology is well understood and has been attractive to mankind since antediluvian times. The goldsmiths and silversmiths, more than 2000 years ago, developed a variety of methods for the benefit of all mankind, including applying mercury [9] as an adhesive for thin films of metals on sculptures and other objects. Ancient mercury-based techniques, such as fire gilding and silvering techniques, were used for the surface coating of less precious substrates with thin layers of gold or silver [10].

Gold was very likely the first metal discovered by humans more than 11,000 years ago. However, unlike copper ( $9000 \mathrm{BC})$, bronze ( 3500 BC), and wrought iron $(\sim 2500-3000 \mathrm{BC})$, gold is too soft for the fabrication of tools and weapons; instead, it was used for decoration, religious artefacts, and commerce. The earliest documented inorganic thin films were gold layers, some less than $3000 \AA$ thick, produced chemo-mechanically by Egyptians during the Middle Bronze Age approximately 5000 years ago, for decorative (and later, optical) applications [10-12]. Gold films with thicknesses < $3000 \AA$ ( 1465 atoms) have been found in ancient tombs, including the Pyramid of Djoser (actual name, Netjerykhet, second King of the Third Dynasty, Old Kingdom, who ruled from 2667 to 2648 BC) in Saqqara [10,13-15] southwest of Cairo, Egypt. The gold used to produce early thin films was mined by Egyptians in the Eastern Desert between the Nile River and the Red Sea. Ancient mining sites in Wadi Hammamat, along the trade route from Thebes (modern-day Luxor) to the Red Sea port of Al-Quseir, are accurately located on a papyrus map drawn by a scribe of Ramses IV during a quarrying expedition in approximately 1160 BC $[16,17]$ and are now on display in Museo Egizio, in Turin, Italy. Today, gold leaf can be beaten to $500 \AA$ thick (partially transparent to visible light) by highly skilled craftsmen [18-20]. Highly skilled ancient Egyptian craftsmen mastered the art of gold sheathing - the direct application of thin gold layers onto wooden and plaster objects (mostly for noble families) to provide the impression that the object was solid gold-at least as early as 2600 BC [21,22]. Striking examples were found in the tomb of Queen Hetepheres (wife, and half-sister, of Pharaoh Sneferu, Fourth Dynasty, Old Kingdom, 2613-2589 BC). Other spectacular examples of early thin film technology were found in the tomb of Pharaoh Tutankhamun ("King Tut", 18th Dynasty, ruled 1332-1323 BC).

It must be noted that an autocatalytic solution-growth technique involving oxidation/reduction reactions was developed by the Moche Indians, who utilized minerals available in the local area, the northern highlands of Peru, to deposit gold and silver films on copper and bronze artefacts beginning in $100 \mathrm{BC}$ [23]. The technique is still in use today, although it is carried out in a more efficient manner, and is referred to as electroless plating [24]. The workmen developed thin-film coating technology that is unrivalled by today's processes for manufacturing DVDs, electronic devices, solar cells, and other relevant products and used it on bronze statues, amulets, jewels, and more common objects [9]. Today, several modern analytical and physico-chemical techniques are necessary to reveal these ancient artists' secrets [25,26]. The earliest documented purposefully made inorganic thin films were gold layers that were chemo-mechanically produced for decorative (and later optical) applications by Egyptians during the Middle Bronze Age, more than 5000 years ago [10-12].

In 1650, interference patterns (e.g., oil on water) were observed and interpreted by R. Boyle, R. Hooke, and I. Newton. Thin film growth by sputter deposition, which required 
the development of vacuum pumps and electrical power in the 1600s and the 1700s, is a much more recent phenomenon. First reported in the early 1800s, sputter deposition dominated the optical coating market by 1880 . Preferential sputtering of alloys, sputtering of liquids, multitarget sputtering, and optical spectroscopy for process characterization were all described in the 1800s. Attempts to understand the internal and external physical structure (i.e., morphology) of vapor-deposited thin films began with the discovery and early development of PVD methods by Grove in 1852 and thermal evaporation by Faraday in Yes, it is all right.1857. In the mid-1930s, roll-to-roll sputter coating (on flexible substrates) was introduced. The term "magnetron" dates to 1921. In the late 1800s, measurements of yields and threshold energies were performed, while the measurements of yields with modern data were carried out in the 1930s. The results of the first magnetron sputtering experiments were published in the 1930s. In 1962, the parallel-plate magnetron was described, followed by that of rotatable magnetrons in 1980, and in 1992, tunable "unbalanced" magnetron sputtering was developed. In 1891, radio frequency (rf) glow discharges were reported, while in the early 1960s, modern capacitively coupled rf sputtering systems were developed. In 1969, the modern sputtering theory was published [27].

In 1649, the chemical vapor deposition (CVD) of metal films was performed. Atmospheric arc deposition was reported in the mid-1760s, atmospheric plasmas in 1857, sols in the 1850s, and sol-gel films in 1885.

In 1935, Katherine Blodgett reported a landmark paper showing that multilayers with controlled thickness and composition can be synthesized on solid substrates.

In 1946, Bigelow, Pickett, and Zisman demonstrated the growth of organic selfassembled monolayers (SAMs) via spontaneous adsorption from solution onto $\mathrm{SiO}_{2}$ and metal substrates. In the early 1980s, the first multicomponent adsorbed monolayers and multilayer SAMs were produced.

Langmuir monolayers, LB multilayers, and self-assembled mono- and multilayers have found an extraordinarily broad range of applications [27].

In 1940, industrial manufacturing of coatings emerged for optical, electronic, and mechanical applications and military applications. Thin film technology constituted an integral part of the mass-manufacturing processes in the semiconductor and optical industries in 1965. Thin films of high Tc superconductors were produced in 1990, and thin film processing allowed the tailoring of microstructures of atomic and mesoscopic dimensions ("quantum dots" by PVD, "Cu technology" by electrochemistry applied to integrated circuits). The deposition of highly ordered two- and three-dimensional objects with sizes in the $\mathrm{nm}$ range was developed in 2000. Combinatorial investigation of ternary and quaternary materials systems in 2004 and the investigation of organic coatings led to the emergence of organic electronics (OLEDs, printable circuits) in 2006. The preparation and characterization of the prototypical two-dimensional (2D) material, graphene, and the introduction of reliable solid-state touch screens to communication media (Smartphones) occurred in 2010, along with the development of heterostructures made from 2D materials. Approaches to manufacturing flexible electronic devices consisting of ultrathin materials were developed in 2015 [27].

\section{Applications of Thin Films}

Over time, the applications of thin films have grown exponentially and have become an integral part of both industrial and research processes. The thickness of the films ranges from a few tenths of a nanometer to a few micrometers. Thin films are a very important field of research and application. Applications of thin films may be grouped under the following generic areas: optics, optoelectronics, chemistry, sensors, electrochemistry, energy storage, photochemical energy conversion, and fuel cells, among others (Figure 1). 


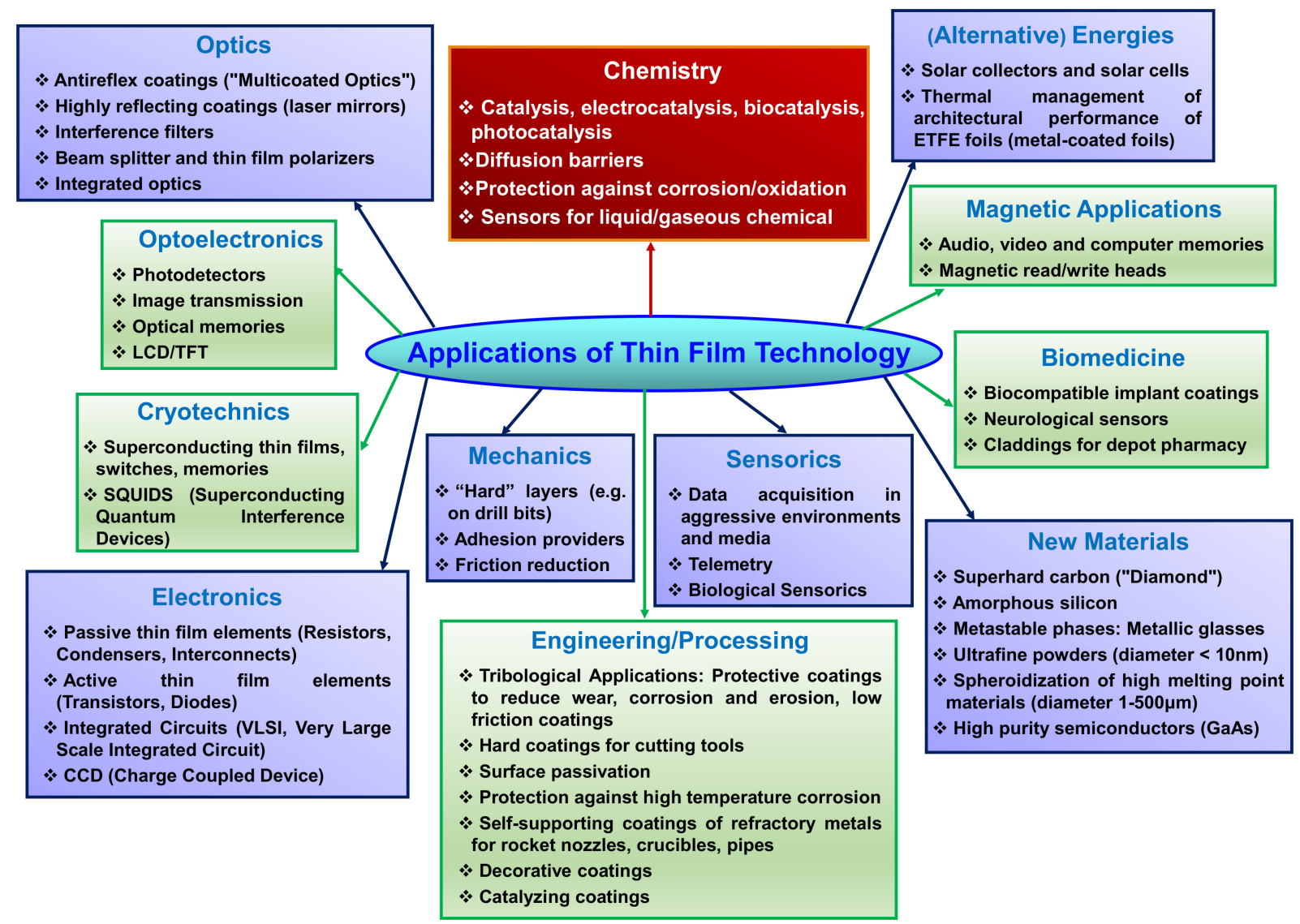

Figure 1. Applications of thin film technology (adapted from Ref. [9]).

Thin film catalysts are also very important as support materials in heterogeneous catalysis, where they are used to stabilize small metal particles as chemically active species. The huge versatility of thin film catalysts allows a wide range of applications; for example, they can be used in emissions control in diesel engines, oxygen storage, hydrocarbon oxidation, three-way catalysts, and hydrogen production (biomass and bio-oil, and via reactions such as gas-water displacement (water-gas shift) and preferential oxidation of CO (Prox) [28-37].

\section{Techniques of Preparation of Thin Films}

Thin film technology is one of the oldest arts, dating back to the metal ages of antiquity, and is one of the newest sciences.

A thin film comprises thin material layers ranging from a nanometer to one micron $\left(10^{-6} \mathrm{~m}\right)$ in thickness. The thickness of the layers deposited makes the distinction between thin film and thick coating depositions. It must be noted that the thin film deposition involves the deposition of individual atoms or molecules on the surface, while thick coating deals with the deposition of particles. A thin film can be designed to have a compositionally homogeneous or an inhomogeneous, depending on the envisaged properties [38].

The steps for obtaining the thin films are as follows $[9,39,40]$ :

- $\quad$ The selection of the material that will be deposited (the target).

- The transport of the target to the substrate.

- The deposition of the target onto the substrate to form a thin film.

- The obtained thin film may be subjected to annealing or heat treatment processes. 


\subsection{Thin Film Growth and Nucleation}

The nucleation mechanisms of thin film growth are classified into three major types:

- Van der Merwe or island growth mechanism. This growth is observed when the adherence between atoms is greater than the bonding between the substrate and the adatoms. A group of stable adatoms accumulates and coalesces on the surface and grows in three dimensions to form an island [41-44].

- Volmer Weber or layer mechanism. This occurs when the adhesion between the atom and the surface is greater than the atom-to-atom bonding. The film grows layer by layer on the surface of the substrate and can be used as a dense coating [41-44].

- Stranski-Krastanov (S-K) mechanism. The S-K mechanism combines both island and growth mechanisms. The adatoms begin to accumulate and form islands after an initial layer has grown.

This classification depends on the interaction between the deposited atoms of the target and the surface of the substrate [41-44]. Deposition techniques determine the properties of the thin film and can also be used to change the existing properties [45,46].

Thin film deposition techniques, presented in this review, are divided into two categories [47,48]: physical deposition process and chemical deposition process.

\subsection{Physical Deposition Process}

\subsubsection{Physical Vapor Deposition (PVD) Process}

PVD is an atomistic deposition process and includes thin film deposition processes that require the condensation of the vaporized material on the surface of solid material under partial vacuum conditions $[49,50]$. In this process, there is a physical discharge of atoms or molecules through a vacuum or low-pressure gaseous or plasma environment and a condensation and nucleation of these atoms onto a substrate. Usually, the phase vapor comprises ions or plasma. During the deposition process, it is possible to introduce reactive gas to the vapor, and the process is called reactive deposition.

PVD processes are used to deposit thin films with thicknesses in the range of a few nanometers to a thousand nanometers.

The PVD process involves three steps [51-54]:

- The formation of vapor-phase species by evaporation, sputtering or ion bombardment of materials to be deposited.

- Migration from the source to the substrate.

- Film growth on the surface. The transported atom or molecule will start to nucleate across the substrate and grow by a number of processes.

In PVD techniques, the atoms, from a solid or molten target, are converted to the gas phase by a physical process. In this case, chemical reactions are absent.

Thin films deposited by PVD methods can be porous or dense, depending on the process parameters, and temperature and pressure have the highest impact on the structure [55].

PVD films can also be applied for multilayer deposition coatings, very thick deposits, and hybrid forms with other deposition techniques [56].

The four processes of PVD are vacuum or thermal evaporation, arc vapor deposition, ion plating, and sputtering.

\section{A. Thermal (or Vacuum) Evaporation}

During the evaporation process, the thermal effect causes an ejection of atoms from the source, whereas during the ion plating process, the growing film is exposed to concurrent ion bombardment.

The steps for thermal or vacuum evaporation are as follows:

- The formation of vapor by sublimation of the target at high temperature.

- The expulsion of vapor from the target and transportation to the substrate.

- The vapor condenses to form a solid thin film on the surface of the substrate. Several deposition cycles lead in thin film growth and nucleation [39]. 
The thermal vaporization rate can be very high compared to other PVD processes $[39,57]$.

The evaporation process has been reported using different configurations. These are molecular beam epitaxy, reactive evaporation, and activated reactive evaporation.

a. The Molecular Beam Epitaxy (MBE) Process

The molecular beam epitaxy (MBE) process is used for epitaxial growing. The epitaxial growing take place through the interaction of distinct or numerous atomic or molecular beams on the surface of a heated crystalline substrate. Evaporation occurs in an ultra-high vacuum. This process has been applied in the manufacturing of semiconductor devices such as cellular phones, transistor conductors, and Wi-Fi [58-61]. The MBE process was discovered by J. R Arthur and Alfred Y. Cho in 1960.

\section{b. The Reactive Evaporation (RE) Process}

The reactive evaporation (RE) process implies the evaporation of metal atoms from a target in a chamber with a reactive gas with the formation of thin film. Reactive evaporation can form stoichiometric oxides and alloys [62,63].

c. The Activated Reactive Evaporation (ARE) Process

The activated reactive evaporation (ARE) process involves the evaporation of atoms from the surface of the target in the presence of plasma. In this case, the plasma increases the reaction rate between the target and the substrate. When the ARE process substrate is held at a negative bias voltage, it is called biased activated reactive evaporation [64-66].

\section{B. Arc Vapor Deposition}

Arc vapor deposition involves one arc at low voltage and high current in order to vaporize the cathodic electrode ( $\mathrm{arc}$ ) and deposits vaporized material on the substrate. In this case, the substrate is biased to attract the film ions to the surface, and the vaporized material is highly ionized [46].

\section{Ion Plating}

The ion plating technique, reported in 1960 [57], involves bombardment (intermittent or continuous) in an inert gas discharge system. In this case, the film can be deposited by atomically sized energetic particles. The substrate is exposed to bombardment that produce sputtering on the surface of the substrate before and during thin film growth $[40,67,68]$. Ion bombardment during film growth facilitates the synthesis of denser films. If a reactive gas is added, the process is called reactive ion plating.

\section{Sputtering}

Sputtering is a nonthermal evaporation process. Individual atoms slip from the target surface due to atomic collision cascades by high-energy ion bombardment [69].

The target-to-substrate distance is shorter, and sputtering can produce films with an improved adhesion and increased thickness [70,71].

The high kinetic energy ions that collide with the surface break free, or sputter, from atoms of the cathode in a process of momentum transfer [72,73].

Sputtering deposition can be obtained in a vacuum with a pressure plasma of $<0.67 \mathrm{~Pa}$ and the sputtered particles are in the straight line and a pressure $\mathrm{f} 0.67$ to $4 \mathrm{~Pa}$, where energetic particles sputtered or reflected are thermalized by gas-phase collision before they reach the substrate surface $[57,74,75]$.

There are several processes: diode sputtering (cathode or radio frequency), reactive sputtering, bias sputtering, magnetron sputtering, and ion-beam sputtering [46,76].

a. Direct Current (DC) Sputtering Uses of a Pair of Planar Electrodes

The target is located at the cathode, and the substrate is positioned at the anode. Ar is introduced between the target and the substrate and is subjected to an electric field to induce ionization and generate a plasma of positive ions and electrons. 
In the DC sputtering system, the target is composed of conducting material [77-79].

With metallic targets, the potential at the cathode is provided by a DC source, but a radio frequency $(\mathrm{RF})$ source is needed for sputtering dielectric materials.

b. Radio frequency (RF) Sputtering

Radio frequency (RF) sputtering is a variant of sputtering. The process involves alternating the electrical potential of the current in a vacuum environment at radio frequencies.

The cathode (the target) becomes the thin film coating, while the anode is connected in a series on the other side of a blocking capacitor. The capacitor is part of an impedance-matching network that provides the power transfer from the RF source to the plasma discharge.

The cathode is bombarded by high voltage at a fixed frequency of $13.56 \mathrm{MHz}$ in a vacuum chamber, which leads to high-energy ions that sputter atoms to become a thin film that coats the substrate [80-82].

Conductive materials can be deposited using a direct current (DC) power supply, and insulators can be deposited by using a radio frequency (RF) power supply.

c. Magnetron

The magnetron uses a magnetic field in order to confine the electrons in the plasma close to the target. During the sputtering process, secondary electrons are emitted from the target as a result of ion bombardment, and magnetron sputtering makes use of the magnetic field to restrict the movement of these secondary electrons to the vicinity of the target.

Magnetic arrays in magnetron sputtering configurations can be varied in situ without tempering with the electromagnet [49,83-86].

d. Reactive Sputter Deposition.

In the deposition chamber, the target reacts with $\mathrm{N}_{2}$ or $\mathrm{O}_{2}$ and forms a thin film on the surface of the substrate. An increase in reactive gas causes the topmost layer of the target material to transform from a single phase to a compound phase, which results in changes in properties such as conductivity, e.g., conductive surfaces become nonconductive, and vice versa. However, it is possible to use inert gases (Ar) and ionized reactive gas, and it is possible to combine nonreactive and reactive gases in the deposition chamber. The resulting deposited thin film is different from the target $[87,88]$.

Pulsed magnetron sputtering (PMS) is an emerging technology which involves short or intermittent pulsing, with a medium frequency range between 10 and $200 \mathrm{kHz}$ of magnetron discharge for tens of microseconds at a low duty circle. The pulsing process leads to the creation of superdense plasma, resulting in the creation of a more uniform thin film [89-92].

\subsubsection{Pulsed Laser Deposition (PLD)}

PLD is a physical method of thin film deposition in which a pulsed laser beam is used to ablate a target composed of the desired thin film material, which is subsequently deposited onto a substrate. A vacuum chamber, with a UV-transparent window through which the laser beam enters the chamber, contains the target and substrate. Outside the chamber, a UV-transparent lens focuses the laser beam onto the target surface. The useful range of laser wavelengths for thin film growth by PLD lies between $200 \mathrm{~nm}$ and $400 \mathrm{~nm}$ for most materials.

PLD permits the fabrication of multicomponent stoichiometric films from a single target.

\subsection{Chemical Deposition Techniques}

There are several types of chemical deposition techniques, in gas phase (CVD, laser chemical vapor deposition, plasma enhanced vapor deposition, photochemical vapor deposition, metal-organic chemical vapor deposition (MOCVD), atomic layer epitaxy) and liquid phase (electro deposition, chemical bath deposition, anodization: molecular beam epitaxy/liquid phase epitaxy, sol-gel/spin coating/Spray pyrolysis technique, ultrasonic $\mathrm{SPT} /$ polymer assisted deposition), but in this review, we focus on the CVD technique. 


\subsubsection{Chemical Vapor Deposition (CVD)}

CVD is a process able to produce a thin film by the contact between the substrate and a volatile precursor. The desired solid material is deposited on a heated substrate surface by a chemical reaction from vapor. The CVD process permits the formation of coatings with a uniform thickness and low porosity [93]. CVD requires a low pressure, but not high vacuum.

CVD is a thermodynamic process involving chemical reactions influenced by temperature, pressure, reaction rates, momentum, mass, and energy transport, while in PVD processes, thin film formation is caused by the condensation of atoms or molecules from vapor phase [94-97]. The quality of the film can be governed and modified by several parameters, such as flow rates, pressure, temperature, chemical species concentration, and reactor geometry $[98,99]$.

CVD easily grows epitaxial film and offers good reproducibility of coatings with the same or similar mechanical, optical, chemical, and physical properties. CVD has the ability to deposit materials which are difficult to produce by other deposition techniques [76,94].

\subsubsection{Thermal CVD}

In thermal CVD, it is necessary to rapidly heat the substrate with lamps and provide the activation energy needed for the reaction to take place. The surface of the material is brought into contact with thermal energy from either the condensing atoms or substrate heater to form the thin film. A thin film with uniform thickness and excellent surface coverage is formed by mobilizing the atoms due to thermal surface energy. The thermal surface energy is a function of the working temperature, and an increase in temperature also results in a better thin film distribution on the surface of the substrate $[100,101]$.

\subsubsection{Laser CVD}

The laser is used for forming the thin films in laser CVD. The focused laser beam is in contact with the locally heated substrate of one or more volatile precursors that react on the surface to produce thin films. The laser occurs because thermal energy produces a coherent, monochromatic, high-energy beam of photons that can be used effectively to drive the CVD reactor for the deposition of the thin film [102-104].

\subsubsection{Photon CVD}

In photon CVD, photons are used to form thin films. Photons, generally ultraviolet (UV) radiation, are necessary as energy in the chemical reaction to break the chemical bonds in the reactant molecules for the deposition of the thin film $[105,106]$.

\subsubsection{Plasma-Enhanced CVD (PECVD)}

PECVD is a way to deposit solid-state thin films from a gaseous state in a reactor chamber with plasma at very low temperature [107-109]. Plasma is used to activate gas-phase chemistry. Plasma is created by an electrical source of energy, which helps to initiate homogeneous reactions for the creation of chemically active ions and radicals that can participate in heterogeneous reactions, which, in turn, lead to thin film formation on the substrate.

\subsubsection{Pulsed CVD—ALD}

Pulsed CVD is also known as atomic layer deposition (ALD) or atomic layer epitaxy (ALE). ALD was developed by Aleskovskii during the 1960s in Russia and was referred to as molecular layering (ML) $[110,111]$. In Finland, in the 1970s, Suntola, developed the atomic layer epitaxy (ALE) technique displays [111]. In the following decades and up until today, the technique was named ALD.

The advantages of the ALD technique are precise thickness control at the monolayer level and self-limiting growth [110,112-114]. Generally, ALD reactions take place in a vacuum, but it is also possible to grow thin films by atmospheric pressure or at lower temperatures. ALD uses only surface chemical reactions to build ultrathin films [113-118]. An ALD reaction has four steps: (1) the chemisorption of the precursor on the surface of 
the substrate; (2) the unreacted precursor and reaction by-products are removed by an inert gas $\left(\mathrm{N}_{2}\right.$ or Ar) purge/pumping and/or by evacuation; (3) in the inert gas, the second precursor (the co-reactant) is pulsed, which reacts with the first precursor solely on the surface (to react with the adsorbed molecules); and (4) the unreacted second precursor and the reaction by-products are removed by purging/pumping [113-116]. Finally, one (sub) monolayer is deposited on the substrate surface. This cycle is then repeated until the desired thickness is obtained [113-117].

ALD and CVD have many similarities and distinctive features. ALD film growth occurs at lower temperatures compared to CVD processes. This low temperature can be explained by the minimization or elimination of gas-phase reactions. Moreover, in the ALD technique, the shadow effect is absent and the growth rate is reduced [113,119-124].

ALD is a vapor deposition technique that is able to prepare thin film materials layer by layer with high conformality, to deposit conformal films on high aspect ratio structures with high uniformity over large areas at low temperatures, self-limiting surface reactions between a gas precursor and a solid surface with control over the thickness [113,125-128]. The film thickness can be governed by the number of ALD cycles and the composition of the film can be controlled with precision.

ALD can use solid, liquid, or gaseous precursors (elements, molecules, or radicals), and they must be volatile. ALD allows the deposition of a wide range of materials as pure elements ( $\mathrm{Au}, \mathrm{Ag}, \mathrm{Pt}, \mathrm{Ru}, \mathrm{Fe}$, etc.) [129-132], binary compounds (e.g., oxides, nitrides, carbides, sulfides, fluorides, such as $\mathrm{Al}_{2} \mathrm{O}_{3}, \mathrm{TiO}_{2}, \mathrm{ZnO}, \mathrm{HfO}_{2}, \mathrm{GaN}, \mathrm{TaC}, \mathrm{CaS}$, and $\mathrm{SrF}_{2}$ ) [113,133-137], and ternary compounds (e.g., $\mathrm{MgAl}_{2} \mathrm{O}_{4}$, TiAlN), polymers, and organic and hybrid materials. The usual reaction temperature is between $100{ }^{\circ} \mathrm{C}$ and $400{ }^{\circ} \mathrm{C}$, and the ideal reaction temperature zone is often described by the so-called ALD window. These features have made ALD a relevant technique for many applications, such as fuel cells [138], metal oxide semiconductor field effect transistors [139], water splitting [140] and purification [141], encapsulation [142], membranes [143], and solar cells [144,145].

\subsubsection{Pulsed Spray Evaporation (PSE)}

CVD is considered a very important method to prepare pure films (with low cost and simplicity) given the easy control of the thickness and morphology of the samples. It is particularly suitable for precursors with limited thermal stability and is well adapted for systematic synthesis of single-phase/doped metals [146,147], spinels [148], or perovskites [149] with tailored composition and morphology on a number of relevant substrates.

The advantages compared to the CVD are the following: metal films can be obtained without employing gaseous hydrogen, there is less demand on the precursor in terms of volatility and stability, and the precursor does not need to be heated for spray evaporation $[150,151]$. The acetylacetonates, which show low toxicity, can be used as precursor and are also readily soluble in ethanol.

\subsection{Plasma Electrolytic Oxidation (PEO)}

Applying the oxidized film created using PEO was attempted in industry in the late 1970s. The early industrial applications mainly focused on generating a coating to prevent the corrosion of the metal or alloy in applications, such as automotive, aerospace, and marine $[152,153]$.

The three-dimensional microstructure produced using PEO make it possible for PEO coatings to be used as catalysts $[154,155]$.

PEO coating formation includes three main stages [156]. In the first stage, on the surface of the substrate, a very important number of discharge channels are formed because of loss in its dielectric stability in a region of low conductivity. The temperature in the channel is heated rapidly, and can reach 10,000 K [157-160]. The anionic components are drawn into the channel under a strong electric field. For example, as aluminum and alloy elements are concomitantly melted out of the substrate, they enter the channel and are oxidized as a result of the high temperatures. Subsequently, the oxidized aluminum is 
ejected from the channel [161] on to the coating surface in contact with the electrolyte. Thus, the coating thickness grows during this stage. In the final stage, the discharge channel cools down rapidly as the micro-discharge is extinguished and the reaction products of electrolysis are deposited on the metal surface. These three stages occur at every discrete location throughout the coating surface, which ensures an even increase in coating thickness.

Generally, the thickness of the coating increases approximately linearly with time under constant current [162]. The coating is a mixture of anodic oxidation, thermal oxidation, and plasma-chemical reactions [163].

\subsubsection{Direct Current (DC)}

DC power supply was mainly used on a lab scale for thin PEO coating formation before the 1970s [164] and was developed to improve the controllability and flexibility of the PEO process.

The limitation of using DC power is the difficulty in regulating the discharge [165]. As the discharge duration is controlled by inserting the interruption pulse, the temperature during the PEO treatment is hence adjustable.

\subsubsection{Alternating Current (AC)}

With AC power supply, the additional polarization of the electrode can be avoided, and this allows control of the discharge duration. The local discharge intensity becomes larger, which assists in increasing the temperature of the electrode surface [166] when an AC with short pulse rise time is applied. It has been reported that a more thermally stable phase PEO coating will be generated [167]. The microstructure and properties of the coatings can be tailored by careful selection of electrical parameters [168].

\subsubsection{Pulsed Bipolar Current (PBC)}

The PBC power supply has been developed with electrical parameters, such as allowing accurate control of the pulse rise time compared to an AC power supply. In addition, PBC allows coating synthesis at higher power and a wide range of frequencies. The importance of the pulse initiation delay and duration using $\mathrm{PBC}$ at high frequency (up to $\mathrm{kHz}$ rage) has been reported [169].

\section{Thin Films Catalysts for Combustion Process}

\subsection{Thin Films in Noble Metal Catalysts}

Pd in a supported form, primarily obtained by the wet impregnation method, is the most known catalyst for methane oxidation; however, its major drawback is represented by sintering of the Pd particles, which occurs at high temperatures.

The formation of a core shell structure by surrounding the active metal particles with a thin shell of oxides can reduce the sintering process and even improve the activity in combustion processes [170-172]. The interaction between Pd and other oxides, such as ceria or zirconia, has proved to promote the oxidation reaction [170,173-176], as well high methane oxidation rates with good thermal stability for alumina-supported Pd catalysts [170-172], although the Pd ceria shell catalysts showed sensitivity to water exposure [177].

Depositing oxides as additional layers onto a metal catalyst already supported can be realized by atomic layer deposition (ALD), achieving uniform oxide films after repeated reaction between the substrate surface and an organometallic precursor, followed by an oxidation process of the deposited compound [178].

The layer thickness of the oxide film is dependent on the number of deposition cycles. This method was able to stabilize Co oxide-based materials for reactions in solution phase by covering the surface of catalysts with an insoluble oxide, namely titania, overcoming the leaching issue [179]. Moreover, the sintering of $\mathrm{Pd} / \mathrm{Al}_{2} \mathrm{O}_{3}$ and $\mathrm{Ni} / \mathrm{Al}_{2} \mathrm{O}_{3}$ was prevented after deposition of an alumina coating, then heating the overlayers in order to induce pores in the ultimately deposited alumina $[180,181]$. 
Thin films of $\mathrm{ZrO}_{2}$ with $1 \mathrm{~nm}$ thickness were deposited onto a $\mathrm{PdO} / \mathrm{Al}_{2} \mathrm{O}_{3}$ catalyst in order to reduce the $\mathrm{Pd}$ sintering after high-temperature calcination [182]. The desired thickness was achieved after 50 deposition cycles since the film growth was evaluated to be $0.02 \mathrm{~nm} /$ cycle and the deposition was realized on both oxidized and reduced $\mathrm{Pd}$ catalysts. The effect of the calcination temperature on the unmodified $\mathrm{Pd} / \mathrm{Al}_{2} \mathrm{O}_{3}$ has been shown as the catalyst calcined at $773 \mathrm{~K}$ displayed methane oxidation rates five times higher compared to the catalyst treated at $1073 \mathrm{~K}$, because of the Pd particle size that increases with the calcination temperature (Figure 2a).
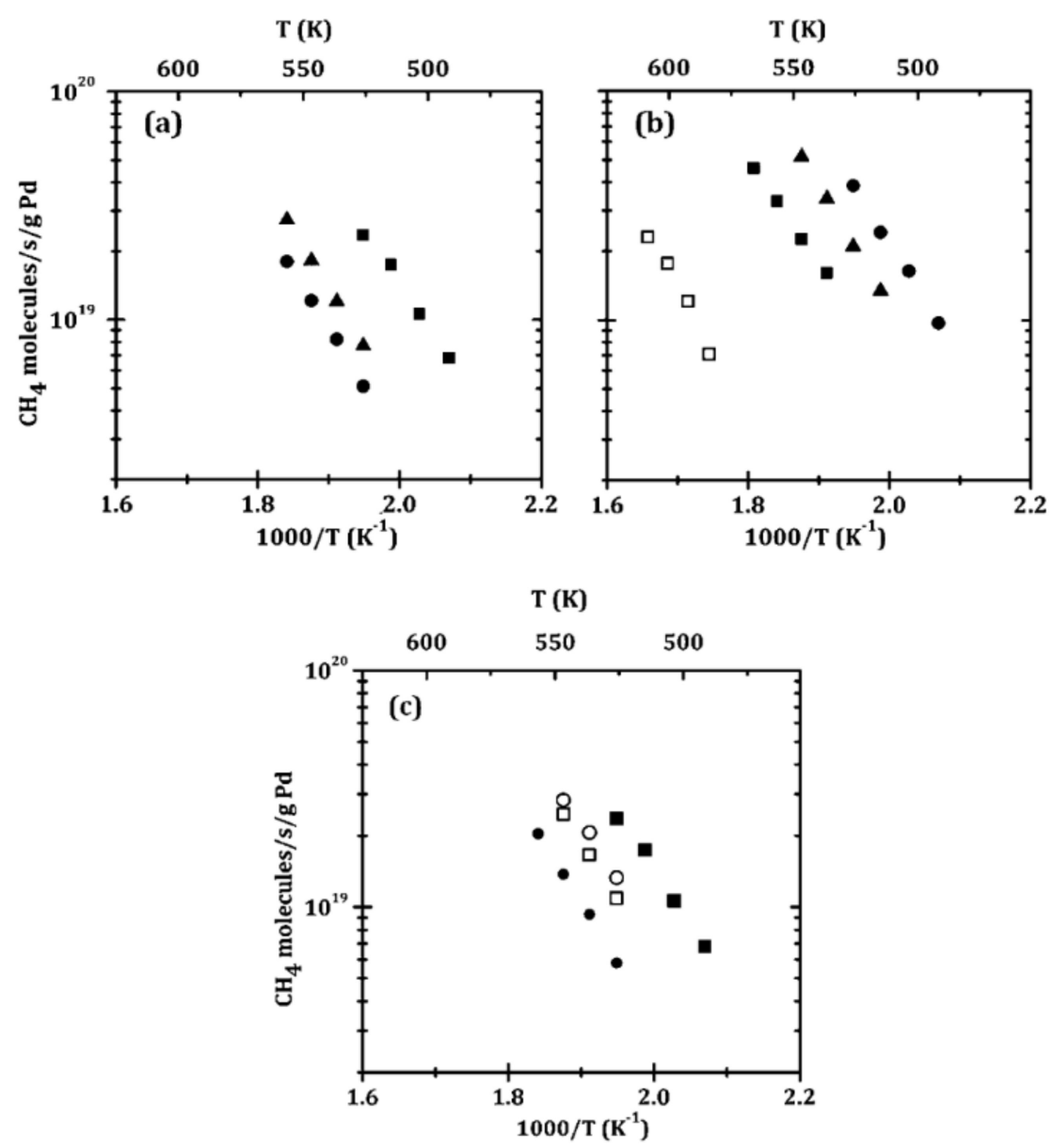

Figure 2. Steady-state, differential reaction rates for methane oxidation. (a) Rates on $\mathrm{PdO} / \mathrm{Al}_{2} \mathrm{O}_{3}$

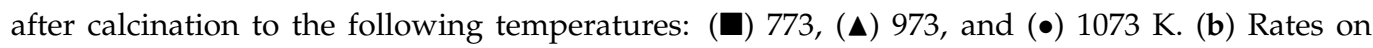
$\mathrm{ZrO}_{2}-\mathrm{PdO} / \mathrm{Al}_{2} \mathrm{O}_{3}$ samples after calcination to the following temperatures: ( $\square$ ) uncalcined, (ם) 773, (ム) 973 , and (•) $1073 \mathrm{~K}$. (c) Rates on $\mathrm{ZrO}_{2}-\mathrm{Pd} / \mathrm{Al}_{2} \mathrm{O}_{3}$, where $\mathrm{ZrO}_{2}$ was deposited by ALD on the reduced catalysts, after calcination at $(\square) 773$ and $(\bigcirc) 1073 \mathrm{~K}$. Data for $\mathrm{PdO} / \mathrm{Al}_{2} \mathrm{O}_{3}$ calcined at $(\square)$ 773 and $(\bullet) 1073 \mathrm{~K}$ are shown for comparison (reprodued from Ref. [182]).

After 50 ALD cycles of $\mathrm{ZrO}_{2}$, the catalyst activity increased interestingly with the calcination temperature. The catalyst treated at $1073 \mathrm{~K}$ was more active than even uncalcined $\mathrm{Pd} / \mathrm{Al}_{2} \mathrm{O}_{3}$, whereas the $\mathrm{ZrO}_{2}-\mathrm{PdO} / \mathrm{Al}_{2} \mathrm{O}_{3}$ sample calcined at $773 \mathrm{~K}$ had lower activity than the unmodified $\mathrm{Pd} / \mathrm{Al}_{2} \mathrm{O}_{3}$ treated at the same temperature, comparing the temperature where the catalysts exhibited a rate of $10^{19} \mathrm{CH}_{4}$ molecules/(s g Pd) (Figure $2 \mathrm{~b}$ ). This behavior indicates that the $\mathrm{ALD} \mathrm{ZrO}_{2}$ films that cover the Pd particles are breaking up at a higher temperature, exposing more surface metal species to oxidize methane, as shown in Table 1. 
Table 1. Pd metal dispersion in different Pd-supported catalysts.

\begin{tabular}{|c|c|c|c|}
\hline \multirow{2}{*}{ Calcination Temperature } & \multicolumn{3}{|c|}{ Dispersion (\%) } \\
\hline & $\mathrm{PdO} / \mathrm{Al}_{2} \mathrm{O}_{3}$ & $\mathrm{ZrO}_{2}-\mathrm{PdO} / \mathrm{Al}_{2} \mathrm{O}_{3}$ & $\mathrm{ZrO}_{2}-\mathrm{Pd} / \mathrm{Al}_{2} \mathrm{O}_{3}$ \\
\hline $773 \mathrm{~K}$ & 32.9 & 10.6 & 18.5 \\
\hline $973 \mathrm{~K}$ & 29.8 & 10.8 & \\
\hline $1073 \mathrm{~K}$ & 24.2 & 13.2 & 18.6 \\
\hline
\end{tabular}

Although the data support the increased exposure at higher calcination temperature to favor $\mathrm{ZrO}_{2}$ film breaking, nevertheless, the activity enhancement of the $\mathrm{ZrO}_{2}-\mathrm{PdO} / \mathrm{Al}_{2} \mathrm{O}_{3}$ sample treated at $1073 \mathrm{~K}$ could be only attributed to the interactions between $\mathrm{Pd}$ and $\mathrm{ZrO}_{2}$. The same deposition of $\mathrm{ZrO}_{2}$ on reduced $\mathrm{Pd} / \mathrm{Al}_{2} \mathrm{O}_{3}$ resulted in samples with similar oxidation rates indifferent to the calcination temperature, more stable than unmodified $\mathrm{Pd} / \mathrm{Al}_{2} \mathrm{O}_{3}$, but with lower rates (Figure 2c). Taking into account these facts, it is proposed that the $\mathrm{ZrO}_{2}$ film did not grow on the metallic Pd, so no Pd particles were covered to influence the surface dispersion of noble metal; however, the zirconia film deposited on the $\mathrm{Al}_{2} \mathrm{O}_{3}$ proves to increase the thermal stability of the $\mathrm{Pd}$ particles. Other works where zirconia was used in combination with $\mathrm{Pd}$ catalysts show that $\mathrm{ZrO}_{2}$ in contact with the $\mathrm{Pd}$ is reducible, with this behavior allowing the stabilization of $\mathrm{PdO}$ phase and the increase in reaction rates [6]. Additional noble metal catalysts were prepared by atomic layer deposition of $\mathrm{Pt}$ onto $\mathrm{ZrO}_{2}$ substrate to study the oxidation of $\mathrm{CO}$ to $\mathrm{CO}_{2}$ on the surface [183]. Besides methane being an important contributor to the pollution and global warming effect, $\mathrm{CO}$ is also known as one of the most toxic components present in the exhaust gases, released by automobiles and numerous industrial plants; therefore, much interest has been focused on the development of catalysts capable of efficient $\mathrm{CO}$ removal [184-186].

ALD allowed the preparation of model catalysts for $\mathrm{CO}$ oxidation reaction with a grown zirconia film on a Si(100) wafer and Pt deposits obtained by different numbers of ALD cycles. The method produced uniform $42 \mathrm{~nm}$ thick zirconia supports (after 400 ALD cycles), whereas several Pt cycles $(10,50)$ afforded small metal particles up to $8 \mathrm{~nm}$ in size. With higher deposition cycles $(125,250)$, the Pt particles start to agglomerate, forming islands and finally, a homogenous Pt film of uniform $10 \mathrm{~nm}$ thickness.

The oxidation of $\mathrm{CO}$ was studied on the 50- and 250-cycle Pt catalysts with the help of near-ambient pressure X-ray photoelectron spectroscopy (NAP-XPS) combined with mass spectrometry (MS) product analysis (Figure 3). Moreover, operando sum frequency generation (SFG) spectroscopy tests revealed that the Pt surfaces were fully covered with oxygen, without adsorbed $\mathrm{CO}$, upon increases in temperature as follows: at $400{ }^{\circ} \mathrm{C}$ for the $\mathrm{Pt}$ thin film (250 cycles) and $450^{\circ} \mathrm{C}$ for the Pt nanoparticles (50 cycles). Both techniques showed that the ignition of $\mathrm{CO}$ on the rougher (50 cycles) $\mathrm{Pt}$ nanoparticles required higher temperature of about $50{ }^{\circ} \mathrm{C}$ than the smoother Pt film.

The results are unexpected, since it was considered that rougher Pt surfaces from nanoparticles are more active in $\mathrm{CO}$ oxidation as their low-coordinated sites bind both oxygen and CO stronger than the highly coordinated sites of smoother surfaces [187]. Nevertheless, NAP-XPS indicated more carbon accumulation on the 50 cycles Pt nanoparticles surface during the oxidation reaction, mostly due to $\mathrm{CO}$ disproportionation according to the Boudouard reaction $\left(\mathrm{CO}^{*}+\mathrm{CO}^{*} \rightarrow \mathrm{CO}_{2}+\mathrm{C}^{*}\right)$ [188]. Taking into account that atomic carbon acts as poison on the low-coordinated active sites for oxygen activation until it is possible to be replaced by oxygen at higher temperature, this behavior explains the higher reaction onset temperature of the $\mathrm{Pt}$ nanoparticles despite their expectedly more active surface, whereas the smoother 250 cycles $\mathrm{Pt}$ film presents less $\mathrm{C}$ poisoning with a lower reaction onset temperature. 

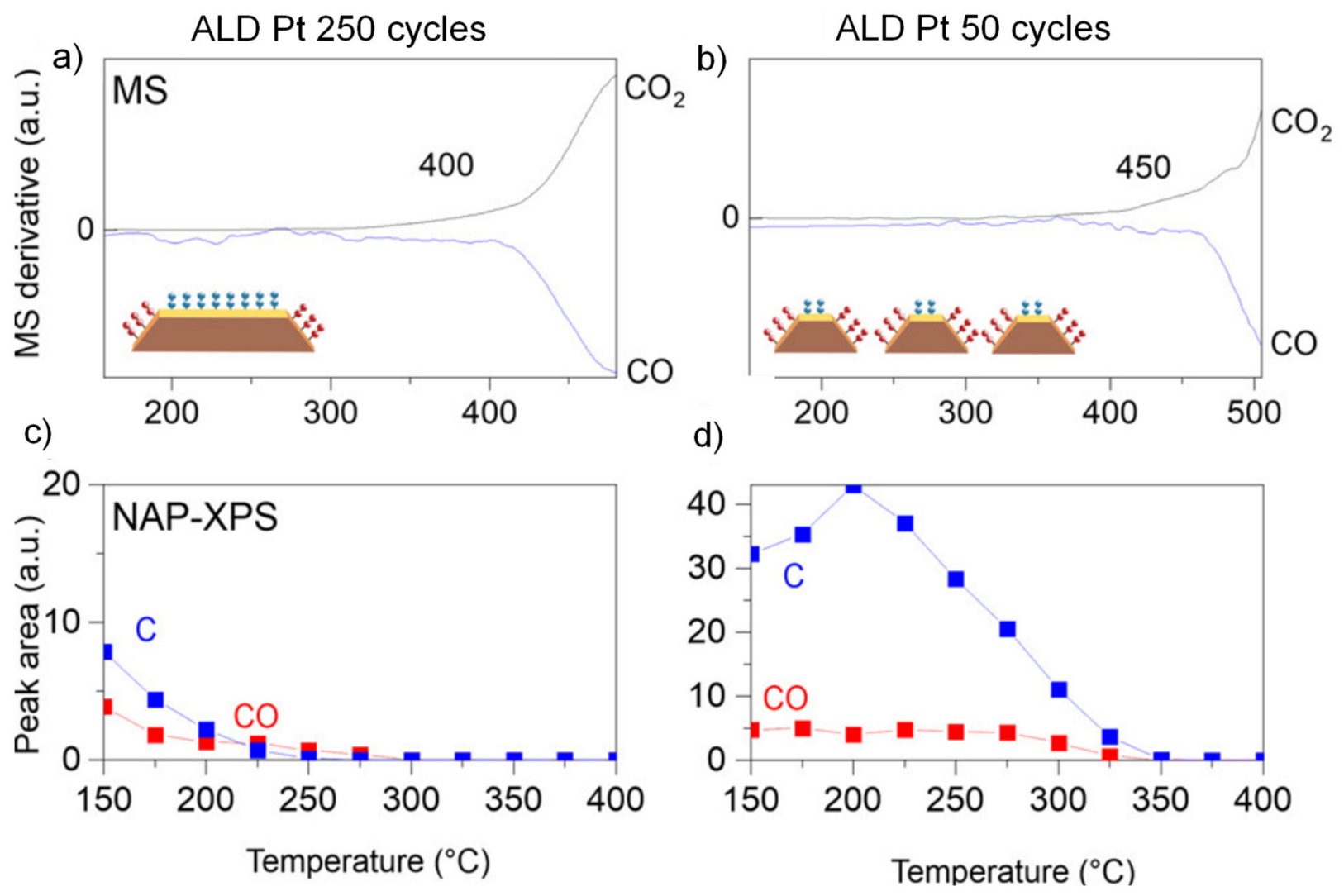

Figure 3. (a,b) Derivatives of the mass spectrometry data of $\mathrm{CO}$ and $\mathrm{CO}_{2}$. (c,d) Temperature-dependent evolution of adsorbed CO and carbon deduced from C 1s NAP-XPS (1 mbar CO, 2 mbar $\mathrm{O}_{2}$; flow mode) (reproduced from Ref. [184]).

Considering these facts, dissociation of $\mathrm{CO}$ occurs via a disproportionation reaction at high coverage of $\mathrm{CO}$ onto the low-coordinated sites, more abundant in the Pt nanoparticles that promote $\mathrm{CO}-\mathrm{CO}$ interaction due to their available structure. Therefore, rougher surfaces are poisoned by deposition of atomic carbon which can be removed to gain active surfaces at $50^{\circ} \mathrm{C}$ higher temperature than the smoother Pt films, showcasing the superiority of the film structure for activity in $\mathrm{CO}$ oxidation reaction.

The catalytic properties of supported noble metal catalysts can be further improved as other oxide layers with combustion activity are deposited. Therefore, a study was realized where the catalytic activities in $\mathrm{CO}$ oxidation were compared for a material obtained by $\mathrm{LaFeO}_{3}$ deposited by ALD onto a prior infiltrated $1 \mathrm{wt} \% \mathrm{Pd} / \mathrm{MgAl}_{2} \mathrm{O}_{4}$ or a $1 \mathrm{wt} \%$ $\mathrm{Pd} / \mathrm{MgAl}_{2} \mathrm{O}_{4}$ sample [189]. The results have shown that the catalysts with ALD-modified layer of $\mathrm{LaFeO}_{3}$ are capable to reactivate by reduction with $\mathrm{H}_{2}$ at $800{ }^{\circ} \mathrm{C}$ for $1 \mathrm{~h}$ after an oxidation process of $1 \mathrm{~h}$ at $800{ }^{\circ} \mathrm{C}$, whereas the activity of $\mathrm{Pd} / \mathrm{MgAl}_{2} \mathrm{O}_{4}$ sample was not recovered after the same reduction at high temperature. Considering these facts, it is suggested that the perovskite layer, which incorporates the Pd atoms, allows a higher $\mathrm{Pd}$ dispersion to inhibit the sintering process at high temperature oxidation, while for the $\mathrm{Pd} / \mathrm{MgAl}_{2} \mathrm{O}_{4}$, the oxidation at $800{ }^{\circ} \mathrm{C}$ caused the Pd particle sintering with no observable redispersion of $\mathrm{Pd}$ atoms after $\mathrm{H}_{2}$ reduction. This indicated that $\mathrm{LaFeO}_{3}$ deposited by ALD can act as support for $\mathrm{Pd}$, also allowing the reactivation of the noble metal catalyst by high temperature reduction, due to higher and uniform Pd distribution. Further studies in $\mathrm{CO}$ oxidation on $\mathrm{LaFeO}_{3} / \mathrm{MgAl}_{2} \mathrm{O}_{4}$ with $\mathrm{Pt}$ deposited by ALD revealed the importance of the interface between the Pt species and the perovskite support, suggesting that the reaction takes place at the $\mathrm{Pt}$-oxide interface, also explaining the decreased activation energy in comparison to the $\mathrm{Pt} / \mathrm{MgAl}_{2} \mathrm{O}_{4}$ [190]. Moreover, the ability to recover its activity after high temperature oxidation-reduction cycles is preserved in the Pt-ALD-modified $\mathrm{LaFeO}_{3} / \mathrm{MgAl}_{2} \mathrm{O}_{4}$, compared to the other tested $\mathrm{Pt}$ catalysts (e.g., $\mathrm{Pt} / \mathrm{FeO}_{\mathrm{x}} / \mathrm{MgAl}_{2} \mathrm{O}_{4}$ in which $\mathrm{FeO}_{\mathrm{x}}$ layer segregation promotes the sintering of Pt particles). 
Numerous studies of catalyst preparation by ALD have started to emerge, but this field is still in its beginnings. This method presents considerable applications to be explored as the possibility to add promoters to metal catalysts, and the variation in the composition of the deposits and the thickness of the grown films are key factors to tune the catalytic activity.

Ceria-based catalysts have gathered interest for their use in VOC combustion because of their superior catalytic activity, combined with excellent oxygen storage capacity/oxygen release capacity (OSC/ORC); thus, they can be utilized as supports for noble metals [191]. The traditional preparation of monolithic catalysts containing mixed oxide solid solution implies multiples steps, which are complex and costly. Among these steps, the deposition of the catalysts in powder form onto supports occurs with reduced adhesion; thus, the obtained catalysts suffer from peeling off and mass loss of active phase, causing catalytic activity degradation.

A different approach to solve is the use of a new route, namely the plasma electrolytic oxidation (PEO) process, which provides favorable adhesion between the substrate and active components. In addition, it is an adequate method to produce metastable/unstable film with tailored element contents having higher activity [165,192,193].

The PEO method was successfully used to synthesize a series of monolithic catalysts containing different mixtures of ceria and zirconia deposited onto flexible titanium mesh, applying their precursor salts in different ratios in the electrolytic process [194].

The titanium mesh works as the anode in the PEO process, being an excellent choice thanks to the high temperature resistance. The PEO film of $\mathrm{Ce}-\mathrm{Zr}-\mathrm{O}$ solid solution contains metastable phase with good substrate adherence at different annealing temperatures. $\mathrm{Ce}-\mathrm{Zr}-\mathrm{O}$ catalysts were loaded with $\mathrm{Au}$ after a deposition-precipitation method and $\mathrm{PdO}$ particles after an impregnation step in order to perform $\mathrm{CO}$ oxidation reaction tests to reveal the tunable catalytic activity of monolithic catalysts with different $\mathrm{Ce}$ and $\mathrm{Zr}$ contents.

The CO combustion test indicated that the most active catalyst among the unmodified Ce-Zr samples was the Ce $75-\mathrm{Zr} 25$ catalyst with a light-off temperature at around $300^{\circ} \mathrm{C}$, due to the highest $\mathrm{Ce}^{3+}$ content at the surface level, evaluated by XPS analysis (Figure 4a). Moreover, the deposition of $\mathrm{Au}$ and PdO onto the initially active Ce 75-Zr 25 PEO film catalysts considerably enhanced the activity in $\mathrm{CO}$ oxidation, reaching light-off temperature of $55^{\circ} \mathrm{C}$ for both, as depicted in Figure $4 \mathrm{~b}$. On the other hand, the catalyst containing Ce 75-Zr 25 annealed at $700{ }^{\circ} \mathrm{C}$ after loading with PdO particles presented a light-off temperature at around $150{ }^{\circ} \mathrm{C}$, showing the superiority of $\mathrm{Ce}-\mathrm{Zr}$-O solid solution to the separated $\mathrm{CeO}_{2}, \mathrm{ZrO}_{2}$ obtained at higher temperature (Figure $4 \mathrm{~b}$ ).
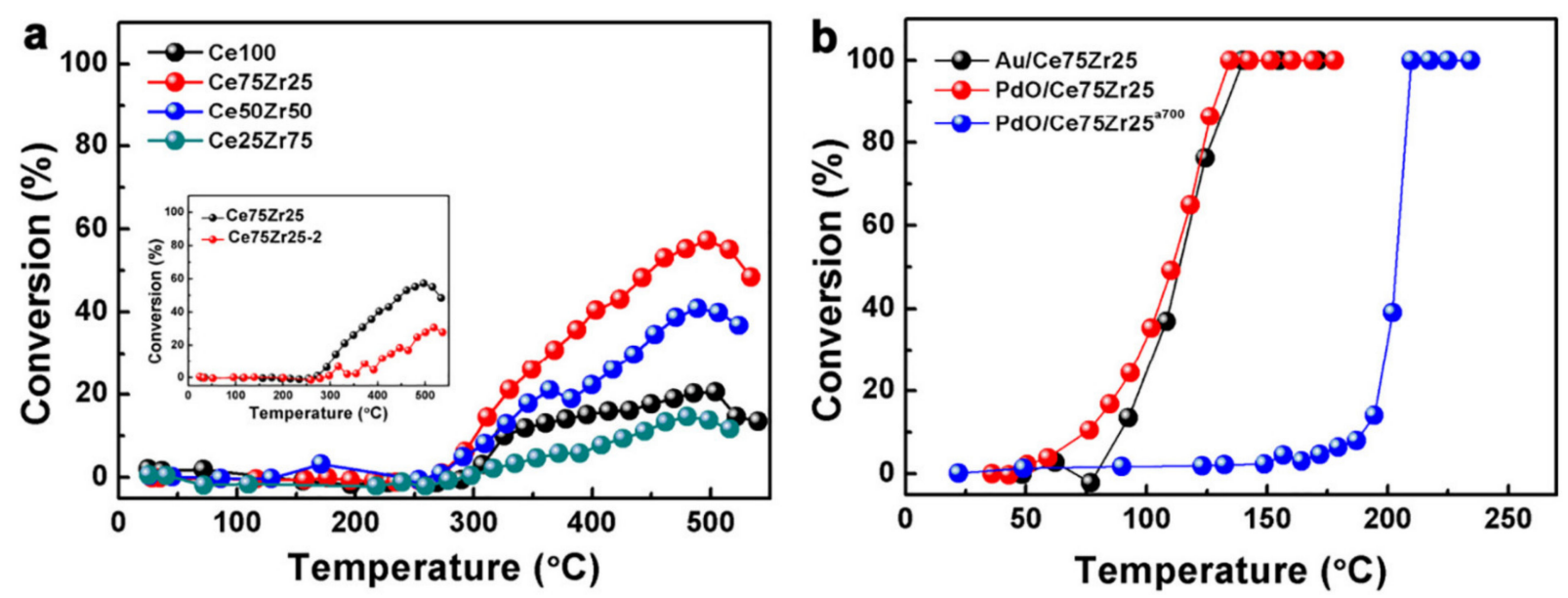

Figure 4. (a) Catalytic CO oxidation light-off curves of as-prepared Ce $(100-x) \operatorname{Zr}(x)(x=0,25,50,75)$ samples. (b) Light-off curves of Au/Ce 75-Zr 25, PdO/Ce 75-Zr 25 and PdO/Ce 75-Zr $25^{a 700}$ (aged at $700^{\circ} \mathrm{C}$ in air for $10 \mathrm{~h}$ ) (reproduced from Ref. [194]).

Thermal stability tests revealed that $\mathrm{Ce}-\mathrm{Zr}-\mathrm{O}$ solid solution keeps its crystal structure and its adhesion as film on the Ti substrate until $700{ }^{\circ} \mathrm{C}$. The PEO method proved to be an 
efficient way to adjust the composition of the film by changing the mass ratio of the $\mathrm{Ce}$ and $\mathrm{Zr}$ salts in the preparation electrolyte.

In addition, after loading the Ce-Zr PEO film with noble metal, the obtained monolithic catalysts showed impressive $\mathrm{CO}$ oxidation activities, with the Pd-supported one being the most active.

These results suggest that there are more opportunities to research the advantages provided by the PEO strategy in the preparation of more stable and active catalysts in VOCs combustion in a more economic approach.

Another work [195] that employs noble metals for CO oxidation focused on the deposition of Au nanofilms on metal fibers using an electron beam evaporation system, thanks to its precise control of this approach over the deposited layer thickness with other superior features [195]. It is an attractive method for large area substrates and a wide range of materials (pure metals, alloys, oxide semiconductors), with no preliminary surface preparation required [196].

Using the electron beam evaporation, thin gold films with a thickness of $\sim 10 \mathrm{~nm}$ were deposited onto the surface of different metal fibers of titanium, zirconium, and $\mathrm{Fe}-\mathrm{Cr}$ - $\mathrm{Al}$ and Ni-Cu-Fe-Mn alloys to study the activity of the modified fibers in CO oxidation [197]. The metal alloy used as a catalytic substrate has a great impact on the properties of the composite with respect to the mechanical, thermal, and chemical resistance under operation conditions [198]. The most known alloys used as supports for catalysts include $\mathrm{Ni}, \mathrm{Cr}$, steel, and finally, $\mathrm{Al}$ alloys, which can protect the catalyst phase with alumina protecting coatings.

The as-prepared metal fibers with $\mathrm{Au}$ films and without noble metal were placed into a quartz reactor to evaluate the catalytic activity in $\mathrm{CO}$ oxidation, as shown in Figure 5.

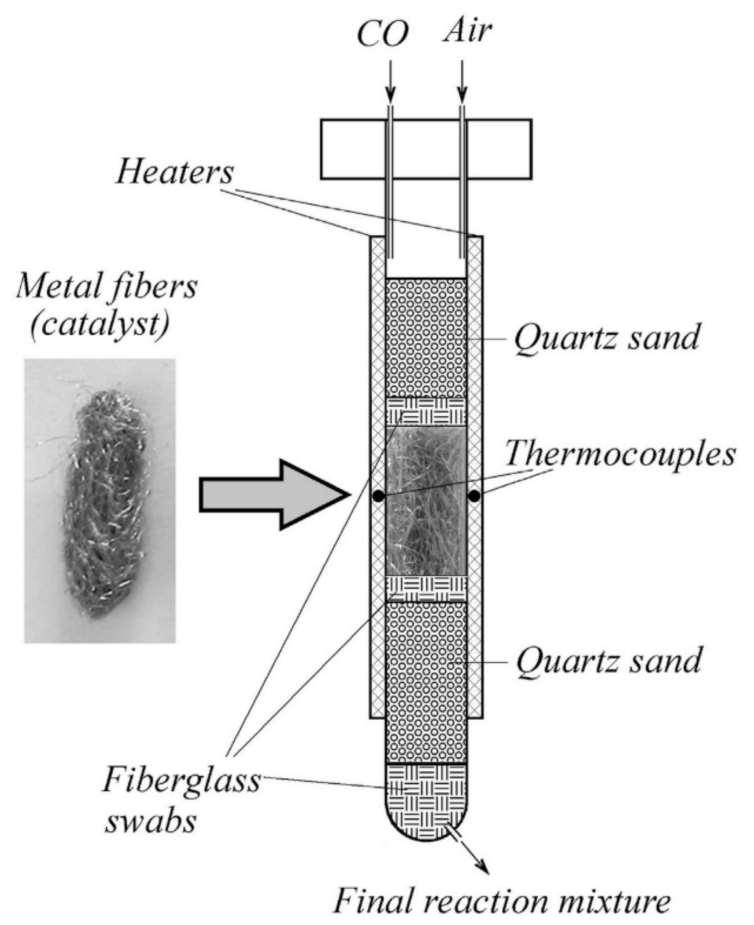

Figure 5. Scheme of the reactor loaded with metal fiber samples.

The light-off curves for CO conversion, depicted in Figure 6, indicate a considerable increase in the activity of the modified fibers after gold deposition, in contrast to the pristine metal fibers. The evaluation of $\mathrm{CO}$ conversion at $500{ }^{\circ} \mathrm{C}$ revealed an increase from $20 \%$ to $67 \%$ for $\mathrm{Zr}$ fibers, from $12 \%$ to $47 \%$ for $\mathrm{Fe}-\mathrm{Cr}-\mathrm{Al}$, and from $4 \%$ to $59 \%$ for $\mathrm{Ti}$ fibers with the most notable gain in activity (up to 15 times). 

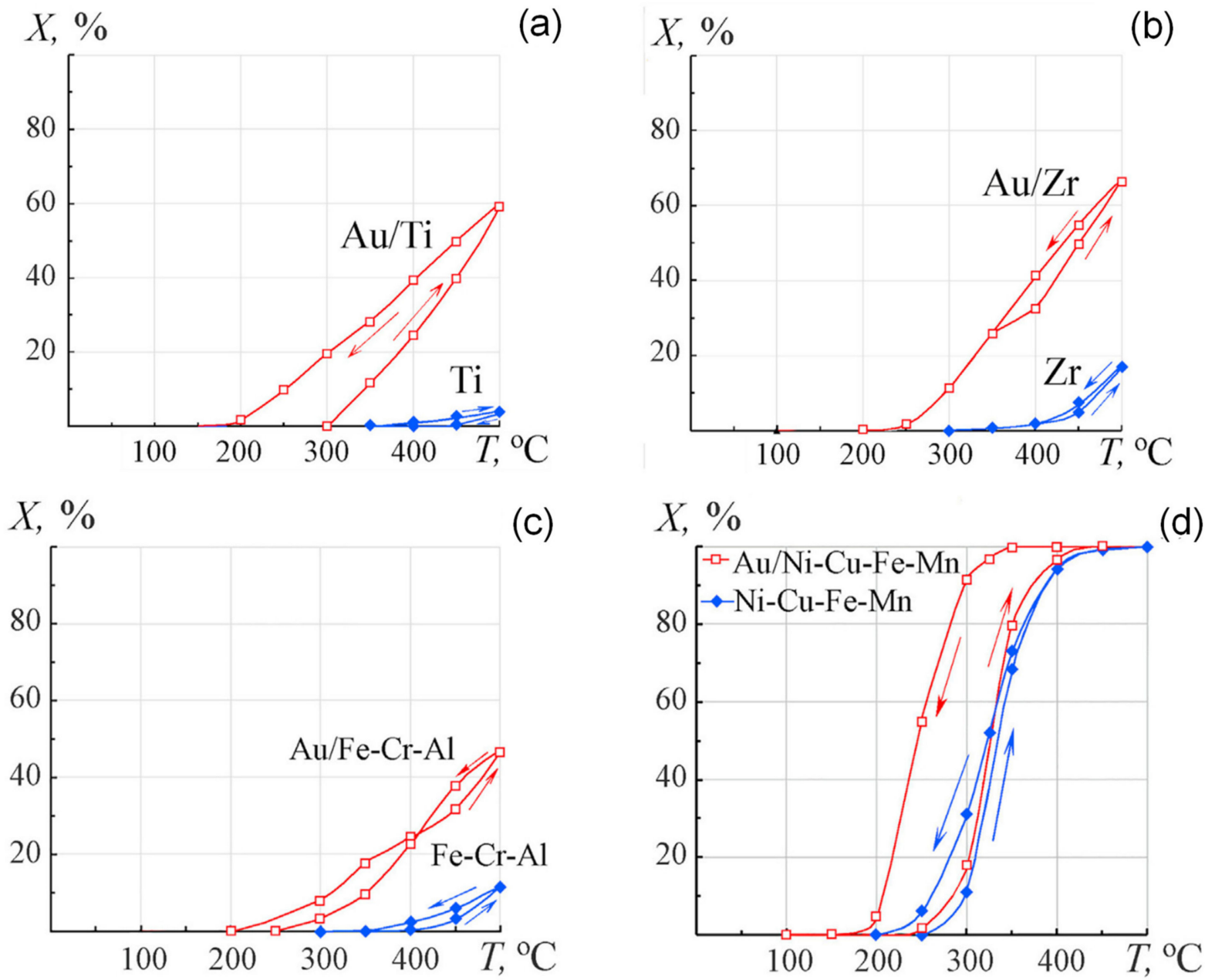

Figure 6. Temperature versus $\mathrm{CO}$ conversion in the first catalytic cycle over the samples of metal fibers from titanium (a), zirconium (b), Fe-Cr-Al alloy, (c) and Ni-Cu-Fe-Mn alloy (d) with and without a gold layer. $\uparrow=$ increase and $\downarrow=$ decrease in temperature (reproduced from Ref. [197]).

Considering these results, the deposition of thin gold films with controlled thickness $(\sim 10 \mathrm{~nm})$ by electron beam evaporation led to an increase in catalytic activity in metal fibers, as follows in the series: $\mathrm{Au} / \mathrm{Fe}-\mathrm{Cr}-\mathrm{Al}<\mathrm{Au} / \mathrm{Zr}<\mathrm{Au} / \mathrm{Ti}<\mathrm{Au} / \mathrm{Ni}-\mathrm{Cu}-\mathrm{Fe}-\mathrm{Mn}$, with light-off temperatures of around $200{ }^{\circ} \mathrm{C}$.

The table below summarizes the aforementioned results regarding the thin films employed in noble metal catalysts for combustion processes, especially including the preparation techniques and the catalytic performances (Table 2).

Table 2. Previous results of thin films used in noble metal catalysts for combustion processes.

\begin{tabular}{|c|c|c|c|c|c|}
\hline Catalyst & Preparation Technique & Active Phase & Test Conditions & Catalytic Performance & Reference \\
\hline $\mathrm{ZrO}_{2}-\mathrm{Pd} / \mathrm{Al}_{2} \mathrm{O}_{3}$ & ALD & $\mathrm{Pd}$ & $\begin{array}{c}0.5 \% \mathrm{CH}_{4}, 5 \% \mathrm{O}_{2} \text { in } \\
\text { He (carrier gas); total } \\
\text { flow rate } \\
110 \mathrm{~mL} / \mathrm{min}\end{array}$ & $\begin{array}{l}\text { Rate of } 10^{19} \mathrm{CH}_{4} \text { molecules/ } \\
\text { (s g Pd) at } 252^{\circ} \mathrm{C}\end{array}$ & [182] \\
\hline $\mathrm{Pt} / \mathrm{ZrO}_{2} / \mathrm{Si}$ & ALD & $\mathrm{Pt}$ & $\begin{array}{l}\text { In NAP-XPS: } 1 \text { mbar } \\
\text { CO, } 2 \text { mbar O }\end{array}$ & $\begin{array}{l}\text { Onset temperature for } \mathrm{CO} \\
\text { oxidation: } 400^{\circ} \mathrm{C}\end{array}$ & [183] \\
\hline $\mathrm{Pd} / \mathrm{LaFeO}_{3} / \mathrm{MgAl}_{2} \mathrm{O}_{4}$ & ALD & $\mathrm{Pd}$ & $\begin{array}{c}0.5 \% \mathrm{CH}_{4}, 5 \% \mathrm{O}_{2} \text { in } \\
\text { He (carrier gas); total } \\
\text { flow rate } \\
120 \mathrm{~mL} / \mathrm{min}\end{array}$ & $\begin{array}{l}\text { Rate of } 3 \times 10^{17} \mathrm{CH}_{4} \\
\text { molecules } /(\mathrm{s} \cdot \mathrm{g} \text { cat }) \text { at } 352{ }^{\circ} \mathrm{C}\end{array}$ & [189] \\
\hline $\mathrm{Pt} / \mathrm{LaFeO}_{3} / \mathrm{MgAl}_{2} \mathrm{O}_{4}$ & ALD & $\mathrm{Pt}$ & $\begin{array}{c}3.3 \% \mathrm{CO}, 1.65 \% \mathrm{O}_{2} \text { in } \\
\text { He (carrier gas); total } \\
\text { flow rate } \\
100 \mathrm{~mL} / \mathrm{min}\end{array}$ & $\mathrm{T}_{50}: 150^{\circ} \mathrm{C}$ & [190] \\
\hline
\end{tabular}


Table 2. Cont.

\begin{tabular}{cccccc}
\hline Catalyst & Preparation Technique & Active Phase & Test Conditions & Catalytic Performance & Reference \\
\hline $\mathrm{Au} / \mathrm{Ce}_{75} \mathrm{Zr}_{25} \mathrm{O}_{2} / \mathrm{Ti}$ & $\mathrm{PEO}$ & $\mathrm{Au}$ & $\begin{array}{c}1 \% \mathrm{CO}, 20 \% \mathrm{O}_{2} \text { in } \mathrm{He} \\
\text { (carrier gas); total } \\
\text { flow rate } \\
10 \mathrm{~mL} / \mathrm{min}\end{array}$ & $\mathrm{T}_{50}: 105{ }^{\circ} \mathrm{C}$ & {$[194]$} \\
\hline $\mathrm{PdO} / \mathrm{Ce}_{75} \mathrm{Zr}_{25} \mathrm{O}_{2} / \mathrm{Ti}$ & $\mathrm{PEO}$ & $\mathrm{Pd}$ & $\begin{array}{c}1 \% \mathrm{CO}, 20 \% \mathrm{O}_{2} \text { in } \mathrm{He} \\
\text { (carrier gas); total } \\
\text { flow rate } 10 \mathrm{~mL} / \mathrm{min}\end{array}$ & $\mathrm{T}_{50}: 100{ }^{\circ} \mathrm{C}$ \\
\hline $\mathrm{Au} / \mathrm{Ni}-\mathrm{Cu}-\mathrm{Fe}-\mathrm{Mn}$ & Electron beam evaporation & $\mathrm{Au}$ & $\begin{array}{c}5 \% \mathrm{CO} \text { in air; total } \\
\text { flow rate } 50 \mathrm{~mL} / \mathrm{min}\end{array}$ & $\mathrm{T}_{50}: 240{ }^{\circ} \mathrm{C}$ & {$[194]$} \\
\hline $\mathrm{Au} / \mathrm{Ti}$ & Electron beam evaporation & $\mathrm{Au}$ & $\begin{array}{c}5 \% \mathrm{CO} \text { in air; total } \\
\text { flow rate } 50 \mathrm{~mL} / \mathrm{min}\end{array}$ & $\mathrm{T}_{50}: 450{ }^{\circ} \mathrm{C}$ & {$[197]$} \\
\hline
\end{tabular}

\subsection{Thin Films in Transition Metal Oxide Catalysts}

Transition metal oxides are compounds with high activity in combustion reactions, representing the most viable option to replace the more expensive and sensitive noble metal catalysts, thanks to their ability to generate highly active oxygen species $\left(\mathrm{O}^{2-}, \mathrm{O}_{2}{ }^{-}\right.$, $\mathrm{O}^{-}$, and $\mathrm{O}_{2}{ }^{2-}$ ), which catalyze the oxidation of hydrocarbon and carbon monoxide, when exposed to the gas phase containing air or oxygen [199]. Among multiple investigated oxides wherein the catalytic activity and the energy of their metal-oxygen bond were assessed, $\mathrm{Co}_{3} \mathrm{O}_{4}$ was found to exhibit the highest ability to exchange its lattice oxygen with the atmosphere, a paramount property in combustion applications, indicating its strong reducibility and strong nucleophilicity $[200,201]$.

In light of these findings, Bahlawane et al. deposited thin films of cobalt oxide onto stainless steel slices, using chemical vapor deposition (CVD) with cobalt (II) acetylacetonate as precursor [199]. CVD is a versatile process which allows the facile preparation of numerous catalytic materials, inducing special crystalline morphologies, high surface areas for the solids or material gradient in the deposited layer [202]. The $\mathrm{Co}_{3} \mathrm{O}_{4}$ film was produced as a cubic spinel-type with a crystalline size of $30-40 \mathrm{~nm}$ with a thickness layer of $\sim 300 \mathrm{~nm}$. In order to illustrate the catalytic activity of $\mathrm{Co}_{3} \mathrm{O}_{4}$ in alkane oxidation, combustion tests with propane were conducted on the CVD-coated steel slices which showed a significant improvement of the light-off temperature from $450{ }^{\circ} \mathrm{C}$ to $250-300{ }^{\circ} \mathrm{C}$ and the complete oxidation of propane at $600^{\circ} \mathrm{C}$ instead of $680^{\circ} \mathrm{C}$, compared to the raw stainless steel slices (Figure 7a). Investigation of the catalytic activity of $\mathrm{Co}_{3} \mathrm{O}_{4}$ was further carried out for the total combustion of oxygenated hydrocarbons wherein ethanol was used as molecule test, because of its potential as a valuable energy source in the future. A light-off temperature for ethanol combustion at $200{ }^{\circ} \mathrm{C}$ was observed in all cases; however, the $\mathrm{Co}_{3} \mathrm{O}_{4}$ CVD-coated slices achieved complete conversion to $\mathrm{CO}_{2}$ at around $380{ }^{\circ} \mathrm{C}$, whereas the non-coated steel achieved the same result at above $700{ }^{\circ} \mathrm{C}$ (Figure $7 \mathrm{~b}$ ).

Moreover, the stability of the $\mathrm{Co}_{3} \mathrm{O}_{4}$-coated slices was evaluated for the combustion of propane and ethanol at $400{ }^{\circ} \mathrm{C}$, showing a decrease in catalytic performance for propane conversion from $60 \%$ to $25 \%$ after $55 \mathrm{~h}$ on stream, whereas for the ethanol combustion, the deactivation was more pronounced, reaching from conversion of $100 \%$ to $30 \%$ after $10 \mathrm{~h}$ on stream (Figure 8). The deactivation process is mainly attributed to the water molecules which block the active sites of the catalyst with a more drastic decrease in activity for the case of ethanol oxidation where the active site undergoes further reduction of the Co species at the surface level by interaction with ethanol, according to a different mechanism [203].

Nevertheless, CVD represents an inexpensive method to prepare uniform coating on large areas with a precise control over the material composition, and it was able to deposit $\mathrm{Co}_{3} \mathrm{O}_{4}$ in films on steel substrate in order to yield active catalysts for propane and ethanol complete combustion. 

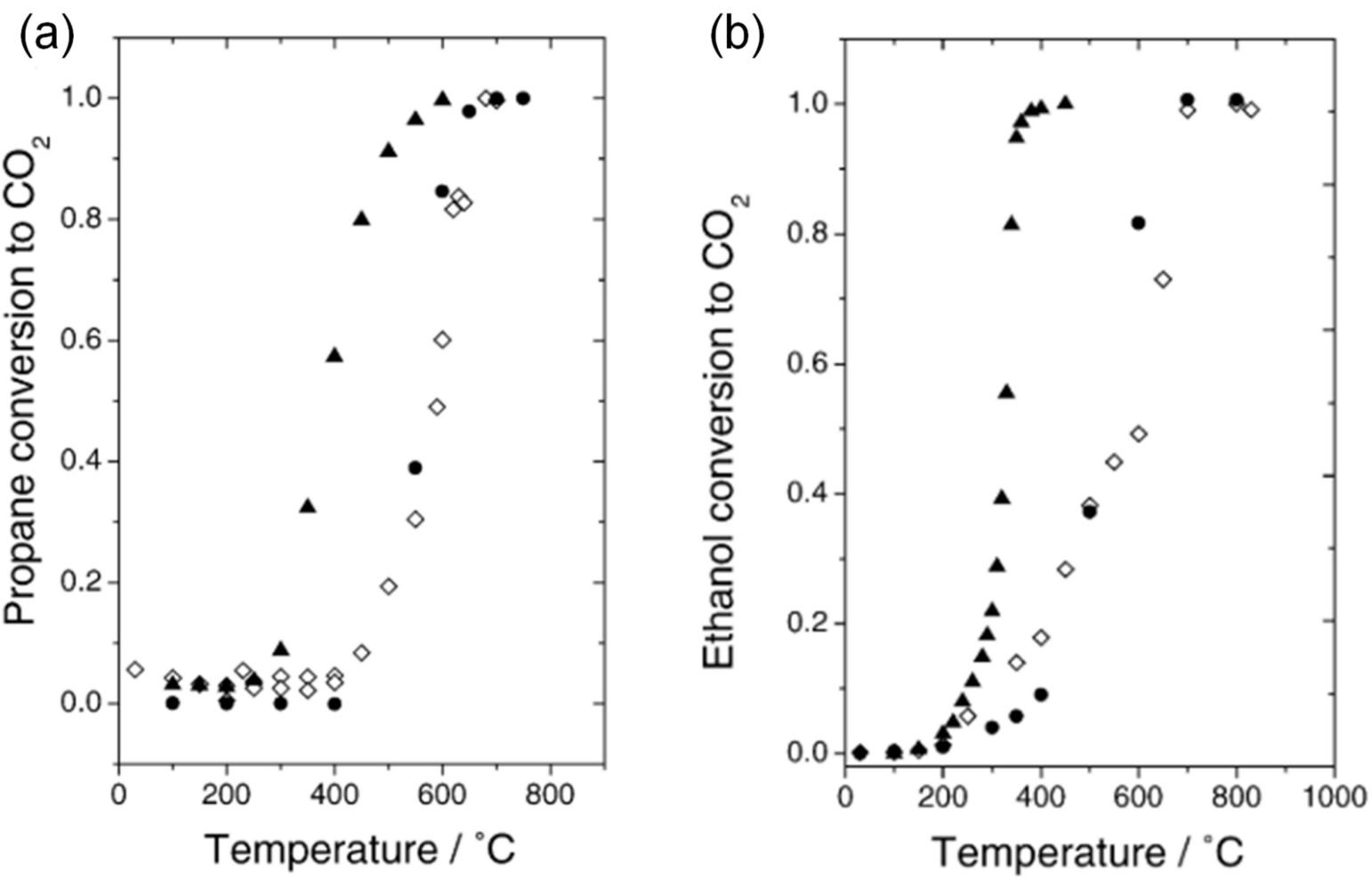

Figure 7. Catalytic tests for total oxidation of propane (a) and ethanol (b) over the steel slices. (•) In free reactor, $(\diamond)$ on stainless steel, and $(\mathbf{\Lambda})$ on coated stainless steel (reproduced from Ref. [199]).
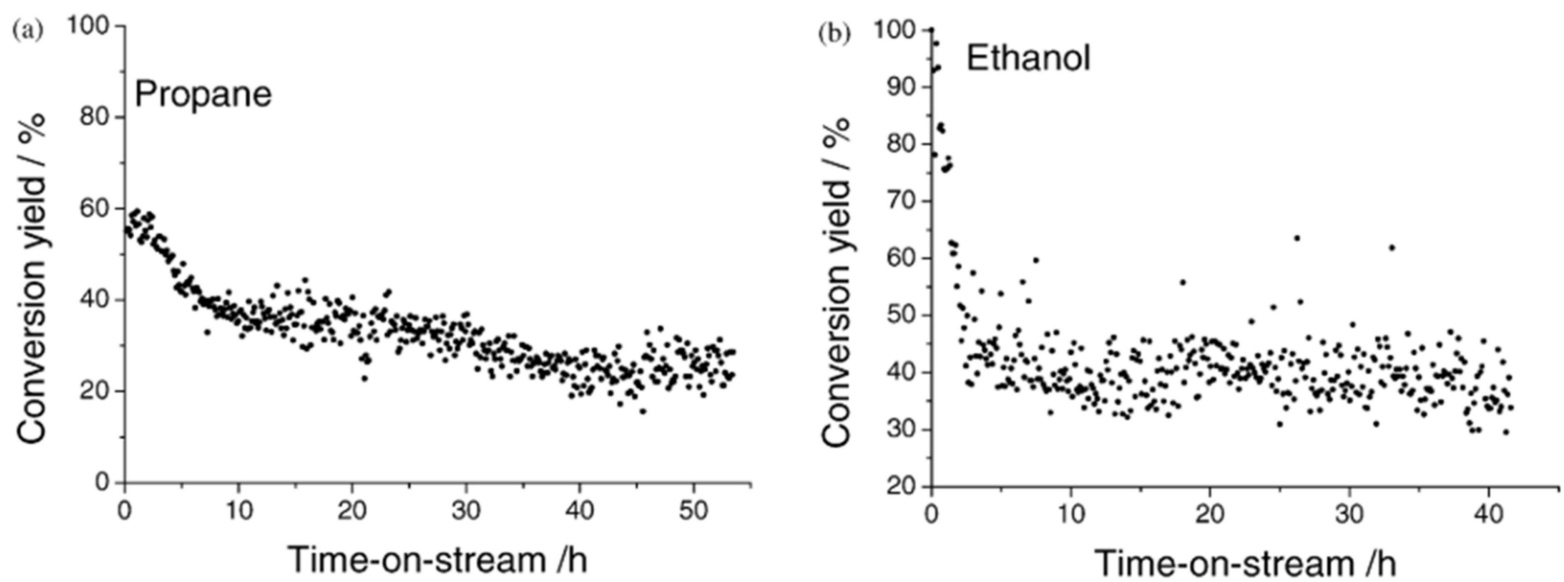

Figure 8. Deactivation of $\mathrm{Co}_{3} \mathrm{O}_{4}$ catalyst during the oxidation process of propane (a) and ethanol (b) at $400{ }^{\circ} \mathrm{C}$ (reproduced from Ref. [199]).

Bahlawane et al. focused on the $\mathrm{Co}_{3} \mathrm{O}_{4}$ active phase as CVD-grown films on monolithic cordierite supports to study the catalytic combustion of methane over cobalt oxide [204]. The CVD process allowed careful control over the growth of thin films, achieving different weight loadings of $\mathrm{Co}_{3} \mathrm{O}_{4}$ onto supports. Methane combustion tests revealed the excellent performance of the catalysts with loadings above $0.46 \mathrm{wt} \%$ which started to oxidize methane at a temperature of $250{ }^{\circ} \mathrm{C}$ and totally convert $\mathrm{CH}_{4}$ to $\mathrm{CO}_{2}$ below $550{ }^{\circ} \mathrm{C}$ (Figure 9). 


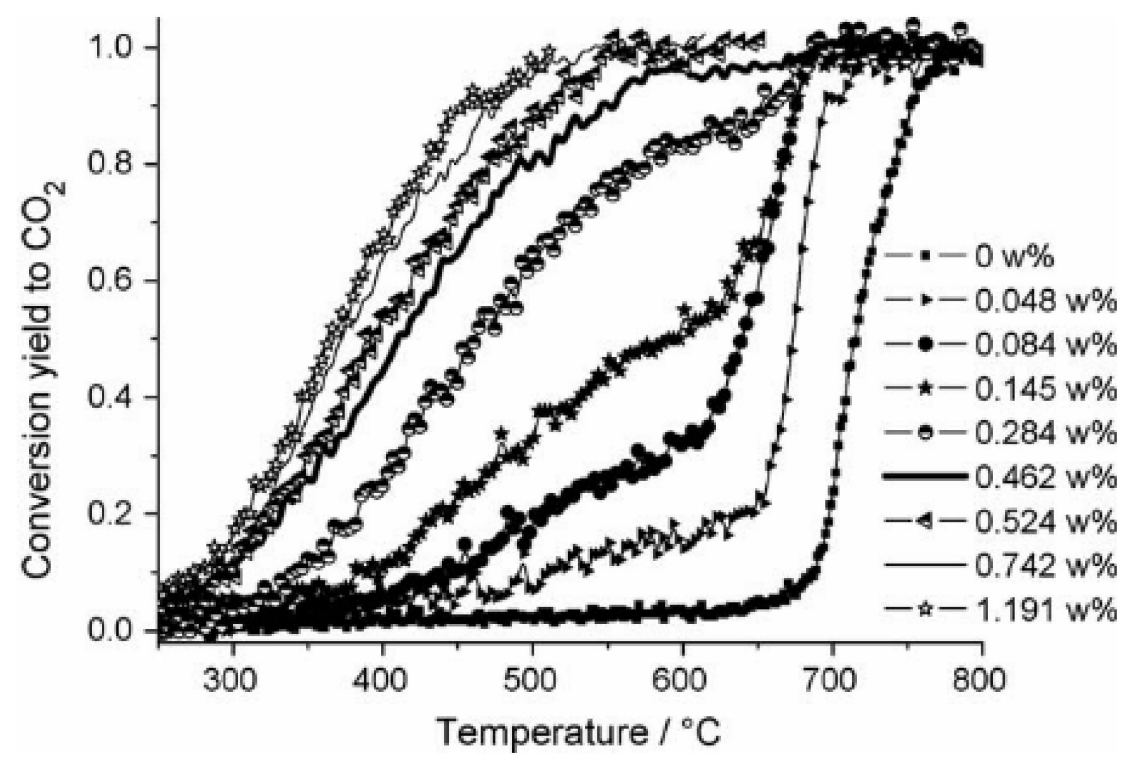

Figure 9. Methane light-off curves over CVD cobalt oxide catalysts as a function of their loadings (reproduced from Ref. [204]).

The catalysts with loadings below $0.46 \mathrm{wt} \%$ displayed the occurrence of two types of reaction: the heterogeneous reaction at low temperatures, which consumes a fraction of methane in accordance with the available surface of cobalt oxide at a specific loading, followed by the homogeneous reaction at high temperature, which leads to an increase in the conversion and also depends on the amount of deposited cobalt oxide, indicating a catalytic assistance to the homogeneous reaction.

Supplementary studies confirm the participation of the bulk cobalt oxide with the function of oxygen bank in the catalytic reaction, according to the Mars-van Krevelen mechanism, which includes a readily migration of oxide ions through bulk diffusion [205,206]. As a matter of fact, the catalytic reaction over $\mathrm{Co}_{3} \mathrm{O}_{4}$ is quite similar to that of $\mathrm{Pd}$, the most efficient catalyst for methane combustion.

In another work, pulsed spray evaporation chemical vapor deposition (PSE-CVD) was employed to obtain thin films of $\mathrm{Co}-\mathrm{Cu}$ binary oxides supported on inert stainless steel grid mesh (SSGM) to study the catalytic combustion of propene $\left(\mathrm{C}_{3} \mathrm{H}_{6}\right)$ [206]. Considered a problematic and harmful pollutant in the atmosphere due to its short-chain unsaturation, propene is encountered in various chemical industries and in motor vehicle and aircraft exhausts $[207,208]$.

The thin films of $\mathrm{Co}-\mathrm{Cu}$ binary oxides were prepared with different molar ratios of metallic elements to observe the impact of $\mathrm{Cu}$ on the catalytic activity of cobalt spinel by evaluating the complete propene oxidation. Likewise, the non-coated mesh (NCM) was tested for $\mathrm{C}_{3} \mathrm{H}_{6}$ oxidation reaction and showed no $\mathrm{C}_{3} \mathrm{H}_{6}$ conversion even at $400{ }^{\circ} \mathrm{C}$, proving that the SSGM is an inert support in the studied temperature range $\left(150-500{ }^{\circ} \mathrm{C}\right)$.

According to the XPS analysis, the $\mathrm{Co}-\mathrm{Cu}$ oxide catalyst with the highest $\mathrm{Cu}$ content had the highest surface content ratio of $\mathrm{O}_{\text {Latt }} / \mathrm{O}_{\mathrm{Ads}}$ and $\mathrm{Co}^{3+} / \mathrm{Co}^{2+}$, and thus showed the superior performance for complete $\mathrm{C}_{3} \mathrm{H}_{6}$ oxidation with a light-off temperature of around $225^{\circ} \mathrm{C}$ and complete conversion at $380^{\circ} \mathrm{C}$, whereas these temperature values were slightly higher for the less $\mathrm{Cu}$-loaded samples (Figure 10).

These results confirm the catalytic enhancement in $\mathrm{C}_{3} \mathrm{H}_{6}$ oxidation for the $\mathrm{Co}-\mathrm{Cu}$ binary oxides systems as more $\mathrm{Cu}$ species are introduced into $\mathrm{Co}$ spinel, which were easily prepared by PSE-CVD. Therefore, the reactivity of mixed oxide thin films obtained by CVD displays great potential in combustion applications. 


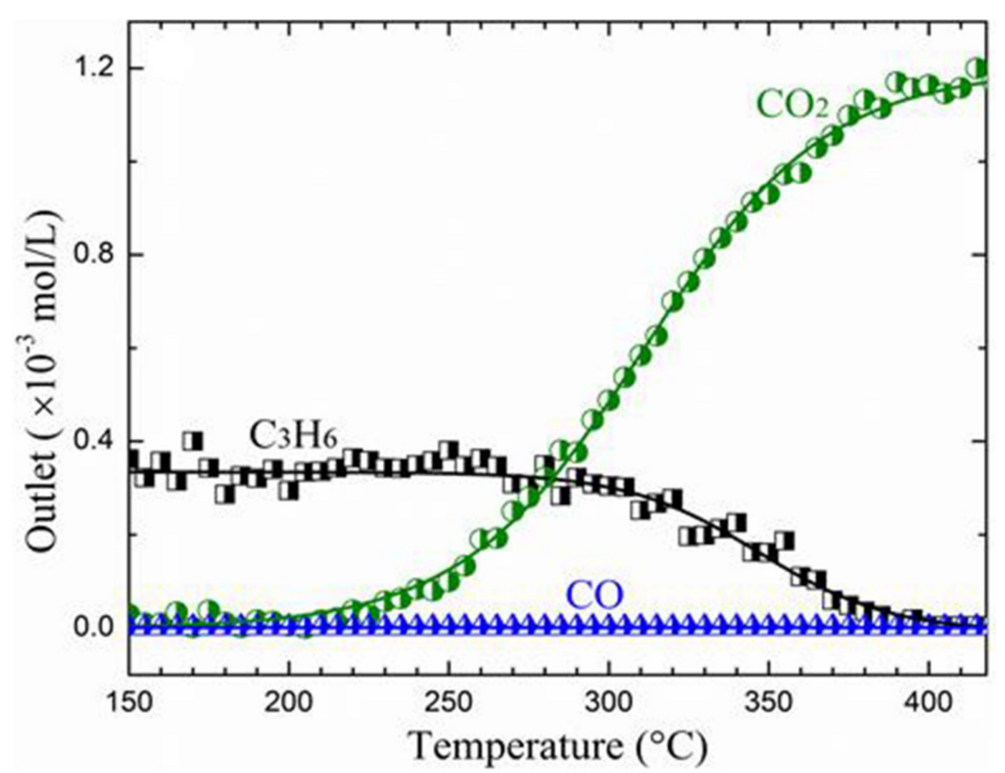

Figure 10. Light-off curves of $\mathrm{C}_{3} \mathrm{H}_{6}$ conversion over the most $\mathrm{Cu}$ loaded catalyst (reproduced from Ref. [206]).

In addition, the application of Co-Fe oxides prepared as films via the PSE-CVD approach were investigated in the VOCs abatement and interesting catalytic activity for the oxidation of $\mathrm{CO}$, dimethyl ether (DME), $\mathrm{C} 3 \mathrm{H} 6$, and n-C4H8 were observed [209-211]. The aim was to compare the catalytic performances of Co-Fe oxides with low and high cobalt content towards different pollutants.

Interestingly, the low Co content spinel (CoFe2O4) obtained $90 \%$ conversion at $260{ }^{\circ} \mathrm{C}$ $\left(\mathrm{T}_{90}\right)$ that was lower than $\mathrm{T}_{90}$ of $298^{\circ} \mathrm{C}$ in the case of the highly Co-loaded spinel. At the same time, $\mathrm{CoFe}_{2} \mathrm{O}_{4}$ was able to achieve complete conversion of $\mathrm{CO}, \mathrm{C}_{3} \mathrm{H}_{6}$, and $\mathrm{n}-\mathrm{C}_{4} \mathrm{H}_{8}$ and DME at 280, 475, 485, and $506{ }^{\circ} \mathrm{C}$, respectively (Figure 11). Moreover, $\mathrm{CoFe}_{2} \mathrm{O}_{4}$ with $\mathrm{T}_{50}$ in $\mathrm{CO}$ oxidation of $243^{\circ} \mathrm{C}$ is quite competitive, overtaking in activity other noble metal catalysts, $\mathrm{Pt} / \mathrm{Al}_{2} \mathrm{O}_{3}\left(304{ }^{\circ} \mathrm{C}\right)$ and $\mathrm{Pt} / \mathrm{CoOx} / \mathrm{Al}_{2} \mathrm{O}_{3}\left(340^{\circ} \mathrm{C}\right)$, as reported in [212].

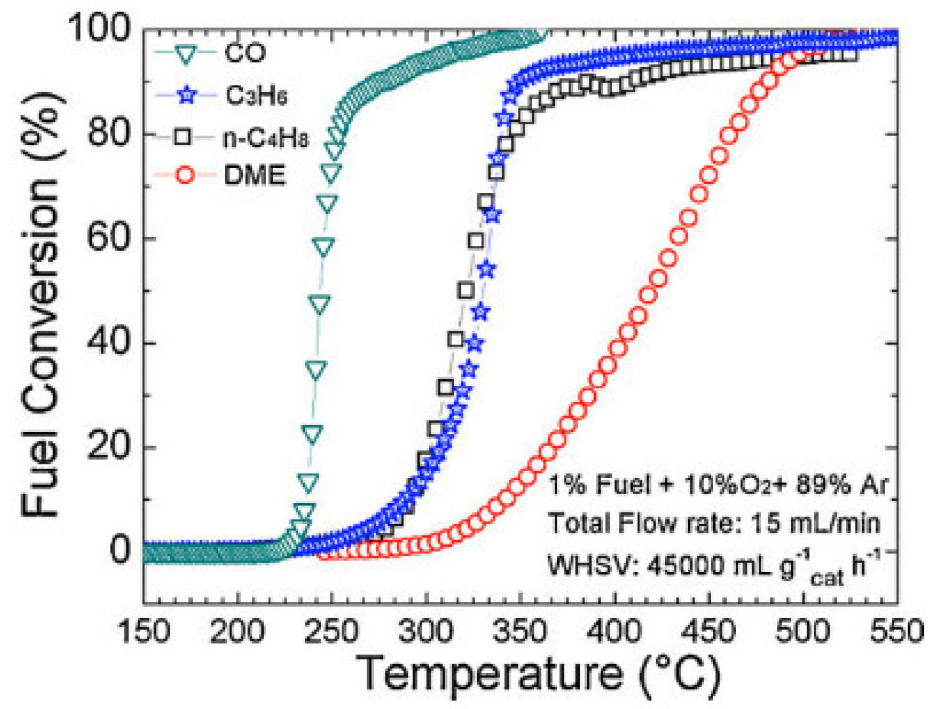

Figure 11. Temperature dependence versus conversion of $\mathrm{CO}, \mathrm{C}_{3} \mathrm{H}_{6}, n-\mathrm{C}_{4} \mathrm{H}_{8}$, and DME in the oxidation reaction over the PSE-CVD-made $\mathrm{CoFe}_{2} \mathrm{O}_{4}$ sample (reproduced from Ref. [209]).

The conversion of $\mathrm{C}_{3} \mathrm{H}_{6}, n-\mathrm{C}_{4} \mathrm{H}_{8}$, and DME indicated that the $\mathrm{Co}_{2 \cdot 1} \mathrm{Fe}_{0.9} \mathrm{O}_{4}$ catalyst has lower temperatures for complete oxidation at 400,425 , and $446{ }^{\circ} \mathrm{C}$, respectively, compared to the $\mathrm{CoFe}_{2} \mathrm{O}_{4}$ sample [210]. The advantage for these Co-Fe spinel systems is that no 
toxic or partial oxidation products are observed, even in the case of DME. The oxidation reaction of DME can include multiple steps that give rise to $\mathrm{CH}_{3} \mathrm{OH}, \mathrm{HCHO}, \mathrm{HCOOCH}_{3}$, and $\mathrm{COx}$ [213]; however, in this study, only $\mathrm{CO}_{2}$ was detected as a product, suggesting that $\mathrm{CoFe}_{2} \mathrm{O}_{4}$ is an highly active catalyst for DME combustion.

Another work aimed at investigating the catalytic combustion of $\mathrm{CO}$ over $\mathrm{Cu}$-doped iron oxides to confirm the increase in activity of iron-based catalysts through a doping strategy. Once again, the one-step synthesis PSE-CVD method was applied to prepare the $\mathrm{FeCuO}_{\mathrm{x}}$ film catalysts on SSGM (noted as CAT1 to CAT4 in the order of Cu content increase) [214].

With the progressive incorporation of $\mathrm{Cu}$ species in the lattice of $\mathrm{Fe}_{2} \mathrm{O}_{3}$, the surface ratio of $\mathrm{O}_{\text {Latt }} / \mathrm{O}_{\text {Ads }}$ in the $\mathrm{Fe}-\mathrm{Cu}$ thin films increases in the following sequence: CAT4 $>$ CAT3 $>$ CAT2 $>$ CAT1. As more lattice oxygen concentrates at the surface of the $\mathrm{FeCuO}_{\mathrm{x}}$ thin films with the copper doping, the catalytic performance in $\mathrm{CO}$ oxidation is presumed to increase [215]. As expected, the highest $\mathrm{Cu}$-loaded catalyst $\left(\mathrm{CAT4}: \mathrm{CuFeO}_{2}\right)$ displayed the lowest temperature for complete oxidation of $\mathrm{CO}$ at $\sim 240^{\circ} \mathrm{C}$ with a light-off temperature of $\sim 170{ }^{\circ} \mathrm{C}$, whereas higher temperatures were observed for the other samples with the decrease in the amount of doping copper (Figure 12).

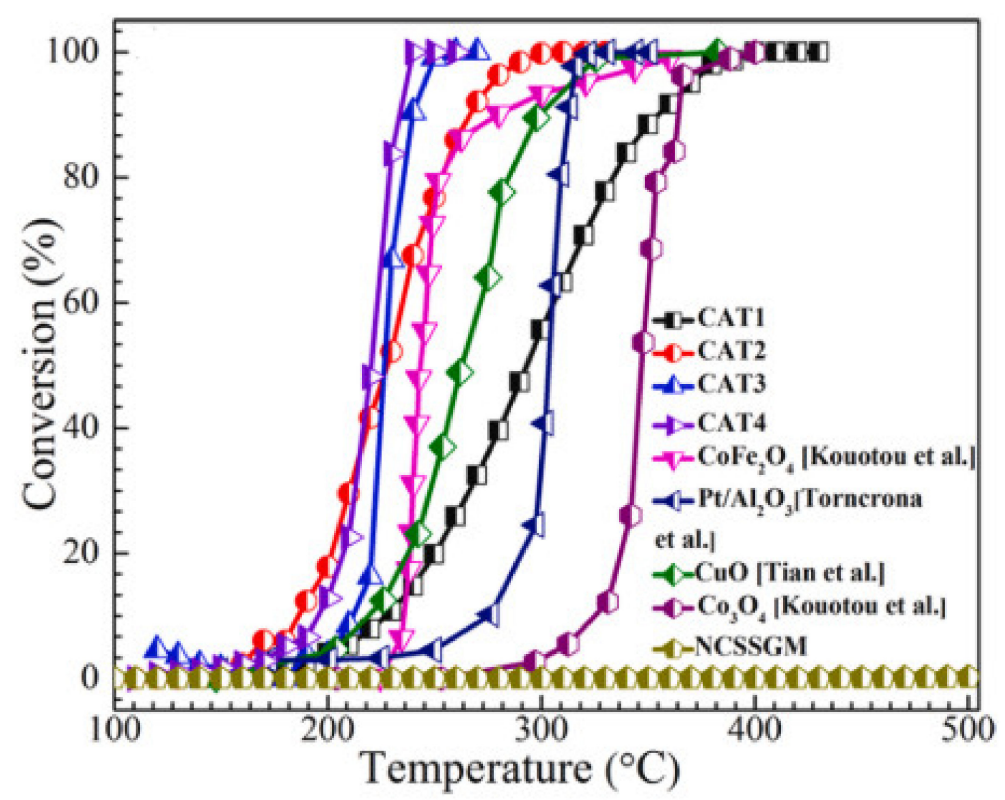

Figure 12. Light-off curves of $\mathrm{CO}$ complete oxidation over $\mathrm{FeCuO}_{\mathrm{x}}(\mathrm{CAT} 1 \rightarrow 4)$ and other known catalysts (reproduced from Ref. [214]).

As more surface oxygen is weakly bounded in copper oxide than in $\mathrm{Fe}_{2} \mathrm{O}_{3}$ [216], the catalytic enhancement of $\mathrm{Fe}_{2} \mathrm{O}_{3}$ can be attributed to the doping with $\mathrm{Cu}$ species, providing more active sites on the surface. At the same time, the $\mathrm{CuO}$ phase can release more oxygen in contact with $\mathrm{CO}$ to favor the oxidation reaction towards $\mathrm{CO}_{2}$.

Moreover, $\mathrm{FeCuO}_{x}$ thin films from CAT4 exceed in catalytic performance most of the known systems studied in $\mathrm{CO}$ combustion, namely $\mathrm{CoFe}_{2} \mathrm{O}_{4}, \mathrm{CuO}, \mathrm{Pt} / \mathrm{Al}_{2} \mathrm{O}_{3}$, and $\mathrm{Co}_{3} \mathrm{O}_{4}$ (Figure 12). It was determined that the presence of two different metal ions in the lattice brings more advantages to oxide catalytic systems compared to a single cationic component, such as high electronic conductivity and abundant redox reactions, crucial in oxidation reactions [217].

The durability test of the $\mathrm{CuFeO}_{2}$ thin film catalyst revealed excellent stability under a stream of fuel mixture at the constant temperature of $226^{\circ} \mathrm{C}$ for $72 \mathrm{~h}$, as signs of severe deactivation were not observed after all the allocated on-stream time the oxidation reaction, showcasing the superiority of the Fe-Cu mixed oxide in terms of activity and durability. 
An additional attempt to develop a more active catalyst for $\mathrm{CO}$ oxidation consisted of the synthesis of $\mathrm{Cu}-\mathrm{Fe}-\mathrm{Co}$ ternary oxides thin films supported on an active copper grid mesh (CUGM) via the PSE-CVD method, including multiple components to enhance the catalytic performance. The use of an active support for CO oxidation, such as CUGM, can considerably enhance the catalytic activity in $\mathrm{CO}$ combustion.

The temperature dependence of $\mathrm{CO}$ conversion over $\mathrm{Cu}-\mathrm{Fe}-\mathrm{Co}-\mathrm{O}$ thin films grown on CUGM indicates that the conversion of $\mathrm{CO}$ is observable at about $110^{\circ} \mathrm{C}$ and that complete combustion occurs at $222^{\circ} \mathrm{C}$, showing increased activity compared to $\mathrm{Cu}-\mathrm{Fe}-\mathrm{Co}-\mathrm{O}$ material coated on inert support (SSGM) (Figure 13).
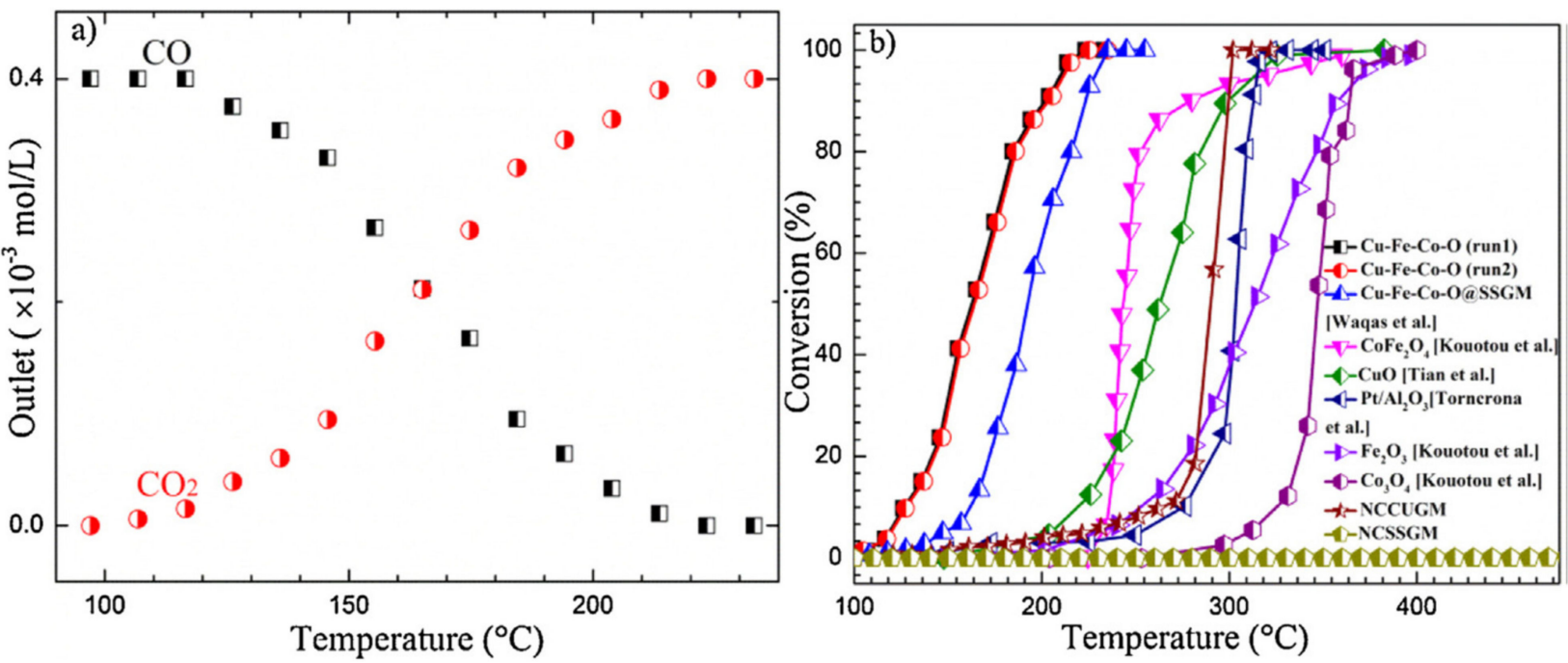

Figure 13. Temperature dependence of $\mathrm{CO}$ conversion over $\mathrm{Cu}-\mathrm{Fe}-\mathrm{Co}$ ternary oxide (a) and the catalytic performance for $\mathrm{CO}$ total combustion over different systems including $\mathrm{Cu}-\mathrm{Fe}-\mathrm{Co}-\mathrm{O} @ \mathrm{CUGM}$ (run 1 and run 2, this work), Cu-Fe-Co-O@SSGM, $\mathrm{CoFe}_{2} \mathrm{O}_{4}, \mathrm{CuO}, \mathrm{Pt} / \mathrm{Al}_{2} \mathrm{O}_{3}, \mathrm{Fe}_{2} \mathrm{O}_{3}$, and $\mathrm{Co}_{3} \mathrm{O}_{4}$ (b) (reproduced from Ref. [218]).

Moreover, the non-coated CUGM presents better activity towards complete CO oxidation than non-coated SSGM, as expected. Taking into account these results, it can be assumed that the integration of an active support greatly improved the catalytic performance of $\mathrm{Cu}-\mathrm{Fe}-\mathrm{Co}$ ternary oxide film by ensuring additional adsorbed active oxygen species.

Compared to other tested systems for $\mathrm{CO}$ oxidation, the $\mathrm{Cu}-\mathrm{Fe}-\mathrm{Co}$ ternary oxide thin film exhibited the greatest catalytic activity in the series as evidenced by $\mathrm{T}_{90}$ : $\mathrm{Cu}$-Fe-Co-O@CUGM $\left(200^{\circ} \mathrm{C}\right)$, Cu-Fe-Co-O@SSGM $\left(224^{\circ} \mathrm{C}\right), \mathrm{CoFe}_{2} \mathrm{O}_{4}\left(260^{\circ} \mathrm{C}\right), \mathrm{Co}_{1.8} \mathrm{Fe}_{1 \cdot 2} \mathrm{O}_{4}$ $\left(250^{\circ} \mathrm{C}\right), \mathrm{CuO} / \mathrm{CoO}\left(247^{\circ} \mathrm{C}\right), \mathrm{Co}_{3} \mathrm{O}_{4}\left(350^{\circ} \mathrm{C}\right), \mathrm{Fe}_{2} \mathrm{O}_{3}\left(366^{\circ} \mathrm{C}\right)$, including noble metal catalyst as $\mathrm{Pt} / \mathrm{CoO}_{\mathrm{x}} / \mathrm{Al}_{2} \mathrm{O}_{3}\left(340^{\circ} \mathrm{C}\right.$ ) and $\mathrm{Pt} / \mathrm{Al}_{2} \mathrm{O}_{3}\left(304^{\circ} \mathrm{C}\right.$ ) (Figure 13). Likewise, $\mathrm{T}_{50}$ of $\mathrm{Cu}$-Fe-Co oxide is $162{ }^{\circ} \mathrm{C}$, an impressive value which indicates high activity at low temperature for $\mathrm{CO}$ oxidation.

The high catalytic performance in $\mathrm{CO}$ oxidation for $\mathrm{Cu}-\mathrm{Fe}-\mathrm{Co}-\mathrm{O}$ thin films was ascribed to the synergistic effect resulted from the interaction of $\mathrm{Cu}^{2+}, \mathrm{Fe}^{3+}$, and $\mathrm{Co}^{3+}$ which significantly enhanced the catalytic activity for the ternary transition metal oxide thin film, reaching much lower temperature in complete conversion of $\mathrm{CO}$, compared to single oxide and binary oxide thin film with fewer metal species in lattice.

At the same time, the stability of CVD-grown ternary oxide film was evaluated by oxidation reaction of $\mathrm{CO}$ for $30 \mathrm{~h}$, revealing a decrease in conversion after $23 \mathrm{~h}$, stabilizing at the end of the reaction at $55 \%$ from the starting $75 \%$ (Figure 14). The decrease in durability can be ascribed to the deposition and accumulation of reaction products on the surface level, resulting in a coverage of the active surface sites of the catalyst [219]. However, even with a degradation in the activity during the oxidation process, the as-prepared thin film has $55 \%$ conversion at $168{ }^{\circ} \mathrm{C}$, which shows a greater reactivity of the $\mathrm{Cu}-\mathrm{Fe}-\mathrm{Co}$ oxide over CUGM compared to other catalytic systems at the same temperature of $168{ }^{\circ} \mathrm{C}$, such as $\mathrm{CuO}$ with $\sim 2 \%$ conversion, $\mathrm{Fe}_{2} \mathrm{O}_{3}(\sim 0.4 \%)$ and $\mathrm{Co}_{3} \mathrm{O}_{4}$, and $\mathrm{CoFe}_{2} \mathrm{O}_{4}$ and $\mathrm{Au} / \mathrm{SiO}_{2}$ with no 
conversion. Thus, the ternary oxide thin films exhibited excellent catalytic activity at low temperature even after $30 \mathrm{~h}$ on stream.

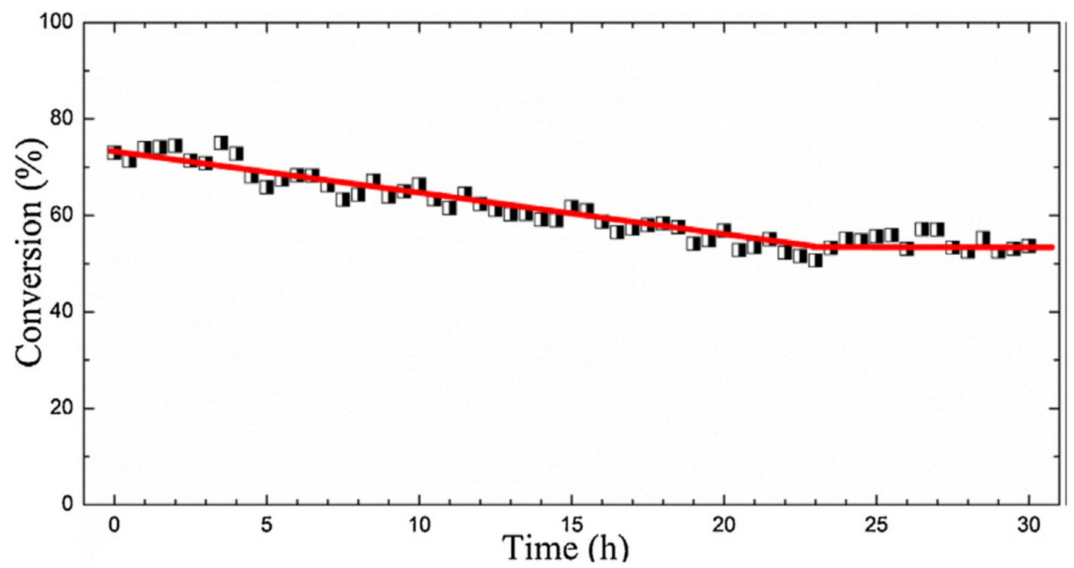

Figure 14. Stability test for the catalytic activity of the ternary oxide system (reproduced from Ref. [218]).

The ternary oxide systems prove to be the successful strategy to prepare highly active catalysts for CO oxidation by PSE-CVD, showing competitive catalytic performance against single and binary metal oxides, also against several noble metals supported on different substrates. These results encourage the development of new ternary oxide catalysts supported on CUGM for combustion application, especially VOCs abatement.

Additionally, PSE-CVD allowed the fabrication of $\mathrm{Mn}_{3} \mathrm{O}_{4}$ thin films on SSGM substates with great thermal stability up to $800{ }^{\circ} \mathrm{C}$ [220]. $\mathrm{Mn}_{3} \mathrm{O}_{4}$ is a transition metal oxide with potential as a catalyst for the oxidation of methane and $\mathrm{CO}$ and for the abatement of VOCs and waste gases. In this sense, catalytic reaction tests over the $\mathrm{Mn}_{3} \mathrm{O}_{4}$ thin film were carried out against $\mathrm{CO}$ and $\mathrm{C}_{3} \mathrm{H}_{6}$ (Figure 15).

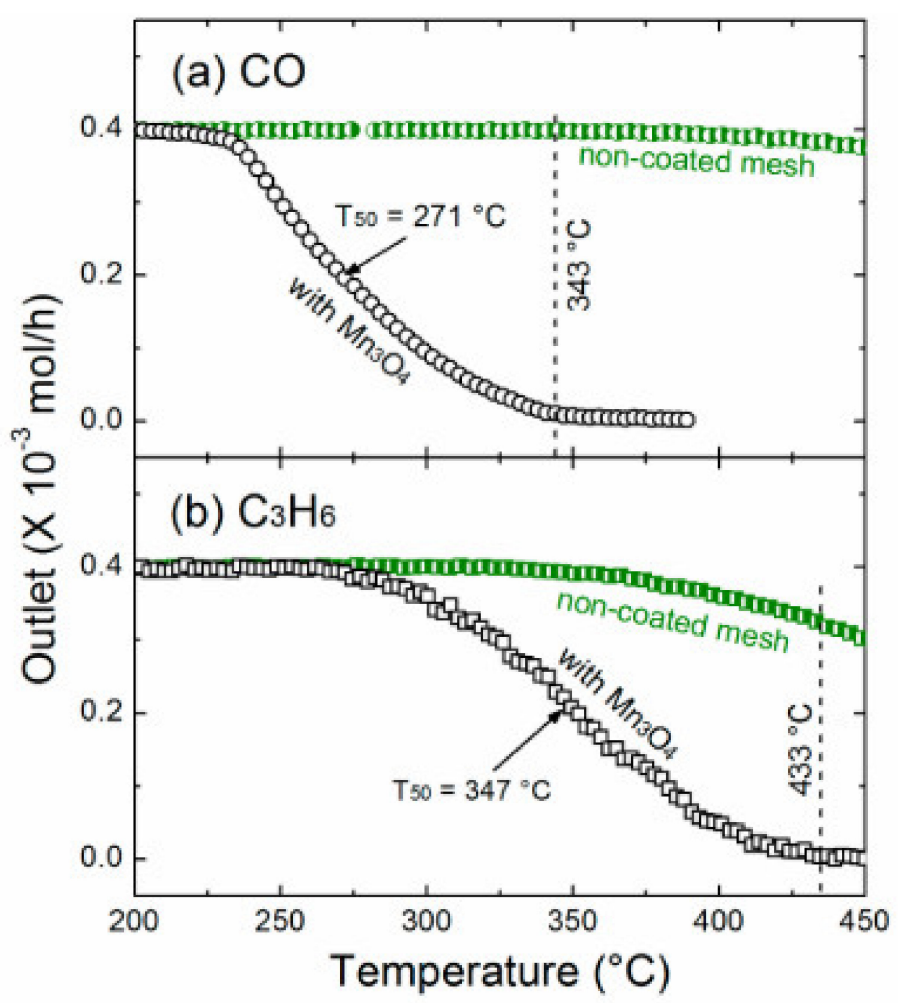

Figure 15. Catalytic test of $\mathrm{CO}(\mathbf{a})$ and $\mathrm{C}_{3} \mathrm{H}_{6}$ (b) oxidation with $\mathrm{Mn}_{3} \mathrm{O}_{4}$. As a reference, oxidation of $\mathrm{CO}$ and $\mathrm{C}_{3} \mathrm{H}_{6}$ was performed on non-coated mesh (reproduced from Ref. [220])). 
In comparison to other active metal oxides, such as $\mathrm{Co}_{3} \mathrm{O}_{4}, \mathrm{CeO}_{2}$, and $\mathrm{Al}_{2} \mathrm{O}_{3}$ with $\mathrm{T}_{90}$ of 350,374 , and $394{ }^{\circ} \mathrm{C}$, respectively, $\mathrm{Mn}_{3} \mathrm{O}_{4}$ achieved complete combustion of $\mathrm{CO}$ at $343^{\circ} \mathrm{C}$, indicating the high activity of the $\mathrm{Mn}_{3} \mathrm{O}_{4}$ thin film. Moreover, the oxidation of $\mathrm{C}_{3} \mathrm{H}_{6}$ over $\mathrm{Mn}_{3} \mathrm{O}_{4}$ occurred with no other by-products, except $\mathrm{CO}_{2}$ and water, and the obtained $\mathrm{T}_{50}$ value of $347^{\circ} \mathrm{C}$ was quite similar to other systems used in $\mathrm{C}_{3} \mathrm{H}_{6}$ combustion.

The Mars-van Krevelen mechanism describes the catalytic oxidation of $\mathrm{CO}$ and $\mathrm{C}_{3} \mathrm{H}_{6}$ over the $\mathrm{Mn}_{3} \mathrm{O}_{4}$ thin film, which includes reversible redox steps of the $\mathrm{Mn}$ species through the exchange of lattice or surface oxygen atoms. During the reaction, the Mn species are reduced at once with the release of oxygen for the oxidation of $\mathrm{CO}$ or $\mathrm{C}_{3} \mathrm{H}_{6}$, then are reoxidized by the atmospheric $\mathrm{O}_{2}$. Hence, the catalytic performance of manganese-based systems in the VOCs combustion is attributed to their reducibility in order to exchange oxygen atoms for the oxidation process.

In summary, the table below presents the aforementioned results regarding the thin films employed in transition metal oxide catalysts for combustion processes, including especially the preparation techniques and the catalytic performances (Table 3).

Table 3. Previous results of thin films used in transition metal oxide catalysts for combustion processes.

\begin{tabular}{|c|c|c|c|c|c|}
\hline Catalyst & Preparation Technique & Active Phase & Test Conditions & Catalytic Performance & Reference \\
\hline $\mathrm{Co}_{3} \mathrm{O}_{4} /$ steel & CVD & $\mathrm{Co}_{3} \mathrm{O}_{4}$ & $\begin{array}{c}2 \% \text { propane, } 4.7 \% \text { Ar } \\
\text { in air; total flow rate: } \\
107 \mathrm{~mL} / \mathrm{min}\end{array}$ & $\mathrm{T}_{50}: 400^{\circ} \mathrm{C}$ & [199] \\
\hline $\mathrm{Co}_{3} \mathrm{O}_{4} /$ steel & CVD & $\mathrm{Co}_{3} \mathrm{O}_{4}$ & $\begin{array}{c}3.2 \% \text { ethanol, } 4.6 \% \mathrm{Ar} \\
\text { in air; total flow rate: } \\
109 \mathrm{~mL} / \mathrm{min}\end{array}$ & $\mathrm{T}_{50}: 300^{\circ} \mathrm{C}$ & [199] \\
\hline $\mathrm{Co}_{3} \mathrm{O}_{4} /$ cordierite & CVD & $\mathrm{Co}_{3} \mathrm{O}_{4}$ & $\begin{array}{c}2 \% \mathrm{CH}_{4}, 20 \% \mathrm{O}_{2} \text { in } \\
\text { Ar; total flow rate: } \\
100 \mathrm{~mL} / \mathrm{min}\end{array}$ & $\mathrm{T}_{50}: 350{ }^{\circ} \mathrm{C}$ & [204] \\
\hline $\mathrm{CoCuO}_{x} / \mathrm{SSGM}$ & PSE-CVD & $\mathrm{Co}_{3} \mathrm{O}_{4}$ & $\begin{array}{l}1 \% \text { propene, } 10 \% \mathrm{O}_{2} \\
\text { in Ar; GHSV: } \\
150,000 \mathrm{~mL} \mathrm{~g}^{-1} \mathrm{~h}^{-1}\end{array}$ & $\mathrm{~T}_{50}: 311^{\circ} \mathrm{C}$ & [206] \\
\hline $\mathrm{CoFe}_{2} \mathrm{O}_{4} / \mathrm{SSGM}$ & PSE-CVD & $\mathrm{CoFeO}_{x}$ & $\begin{array}{c}1 \% \mathrm{CO}, 10 \% \mathrm{O}_{2} \text { in } \mathrm{Ar} \\
\text { total flow rate: } \\
15 \mathrm{~mL} / \mathrm{min} \text {; WHSV: } \\
45,000 \mathrm{~mL} \mathrm{~g}^{-1} \mathrm{~h}^{-1}\end{array}$ & $\mathrm{~T}_{50}: 243^{\circ} \mathrm{C}$ & [209] \\
\hline $\mathrm{CoFe}_{2} \mathrm{O}_{4} / \mathrm{SSGM}$ & PSE-CVD & $\mathrm{CoFeO}_{x}$ & $\begin{array}{c}1 \% \text { propene, } 10 \% \mathrm{O}_{2} \\
\text { in Ar; total flow rate: } \\
15 \mathrm{~mL} / \mathrm{min} \text {; WHSV: } \\
45,000 \mathrm{~mL} \mathrm{~g}^{-1} \mathrm{~h}^{-1}\end{array}$ & $\mathrm{~T}_{50}: 313^{\circ} \mathrm{C}$ & [209] \\
\hline $\mathrm{FeCuO}_{2} / \mathrm{SSGM}$ & PSE-CVD & $\mathrm{FeCuO}_{x}$ & $\begin{array}{c}1 \% \mathrm{CO}, 20 \% \mathrm{O}_{2} \text { in } \mathrm{Ar} ; \\
\text { total flow rate: } \\
20 \mathrm{~mL} / \mathrm{min} ; \text { WHSV: } \\
184,500 \mathrm{~mL} \mathrm{~g}^{-1} \mathrm{~h}^{-1}\end{array}$ & $\mathrm{~T}_{50}: 220^{\circ} \mathrm{C}$ & [214] \\
\hline $\mathrm{CuFeCoO}_{\mathrm{x}} / \mathrm{CUGM}$ & PSE-CVD & $\mathrm{CuFeCoO}_{x}$ & $\begin{array}{c}1 \% \mathrm{CO}, 20 \% \mathrm{O}_{2} \text { in } \mathrm{Ar} \\
\text { WHSV: } \\
75,000 \mathrm{~mL} \mathrm{~g}^{-1} \mathrm{~h}^{-1}\end{array}$ & $\mathrm{~T}_{50}: 162^{\circ} \mathrm{C}$ & [218] \\
\hline $\mathrm{Mn}_{3} \mathrm{O}_{4} / \mathrm{SSGM}$ & PSE-CVD & $\mathrm{Mn}_{3} \mathrm{O}_{4}$ & $\begin{array}{c}1 \% \mathrm{CO}_{1}, 10 \% \mathrm{O}_{2} \text { in } \mathrm{Ar} \\
\text { WHSV: } \\
75,000 \mathrm{~mL} \mathrm{~g}^{-1} \mathrm{~h}^{-1}\end{array}$ & $\mathrm{~T}_{50}: 271^{\circ} \mathrm{C}$ & [220] \\
\hline $\mathrm{Mn}_{3} \mathrm{O}_{4} / \mathrm{SSGM}$ & PSE-CVD & $\mathrm{Mn}_{3} \mathrm{O}_{4}$ & $\begin{array}{c}\text { 1\% propene, } 10 \% \mathrm{O}_{2} \\
\text { in Ar; GHSV: } \\
75,000 \mathrm{~mL} \mathrm{~g}^{-1} \mathrm{~h}^{-1}\end{array}$ & $\mathrm{~T}_{50}: 347^{\circ} \mathrm{C}$ & [220] \\
\hline
\end{tabular}

The thin film approach enables the preparation of highly active catalysts based on noble metal and also transition metal oxide for the complete combustion of $\mathrm{CH}_{4}, \mathrm{CO}$, and other volatile organic compounds. The employed techniques for the film formation (e.g., ALD, PSE-CVD) allow easy, one-step synthesis with complex content and precise control over the component ratio, and offer interesting choices of support substrates to enhance the catalytic activity in combustion processes. 


\section{Conclusions}

Thin film technology is well studied as a forerunner across the world with highly novel scientific developments, and facts establish that thin film technology has been, and will continue to be, invaluable to innovative research on novel applications for societal benefits. Among the major noteworthy developments in different fields of catalysis, thin films by PVD and CVD are the most important worldwide challenges thus far. Thus, research on unique thin film technological achievements might pave the way for coating thin films on an atomic scale that may perhaps be a sign of green energy in the future.

The combustion of $\mathrm{CO}$ is more studied because it can take place more easily than that of $\mathrm{CH}_{4}$ (where bond cleavage is needed); at the same time, it is an indicator of whether or not the catalyst has combustion capacity. The reaction on $\mathrm{CO}$ can also be used in combination with other catalysts to limit $\mathrm{CO}$ emissions from incomplete oxidation to form the less toxic compound, $\mathrm{CO}_{2}$.

The active centers in oxidation are metal ions with redox capacity $(\mathrm{Pt}, \mathrm{Pd}, \mathrm{Co}, \mathrm{Cu}, \mathrm{Fe}$, $\mathrm{Mn}$ ) under unsaturated coordination, according to the Mars-van Krevelen mechanism.

Regarding the support, neutral supports bring thermal stability to the active phase, ensuring sustainable activity and not having redox capacity to contribute to oxidation, while reducible supports bring stability to maintain the activity of the active phase layer, along with extra activity in oxidation reactions, and are able to contribute directly with other active centers or as a source of oxygen in the network by diffusion.

Funding: This research received no external funding. This work has been supported by the Agence Nationale de la Recherche and the FEDER (INSOMNIA project, contract "ANR-18-CE09-0003"). This work has been made within the framework of the Graduate School NANO- PHOT (École Universitaire de Recherche, contract ANR-18-EURE-0013).

Acknowledgments: I. Fechete express gratitude to F. Parent, from the Université de Technologie de Troyes, LASMIS-Antenne de Nogent, for helpful suggestions and discussions concerning PVD process.

Conflicts of Interest: The authors declare no conflict of interest.

\section{References}

1. Duprez, D.; Cavani, F. Handbook of Advanced Methods and Processes in Oxidation Catalysis; Imperial College Press: London, UK, 2014.

2. Ojala, S.; Pitkäaho, S.; Laitinen, T.; Laitinen, T.; Koivikko, N.N.; Brahmi, R.; Gaalova, J.; Matejova, L.; Kucherov, A.; Paivarinta, S.; et al. Catalysis in VOC abatement. Top. Catal. 2011, 54, 1224-1256. [CrossRef]

3. Lintz, H.G.; Pentenero, A.; Le Goff, P. Étude par spectrométrie de masse de la combustion hétérogène des vapeurs organiques sur platine. J. Chim. Phys. 1962, 59, 933-940. [CrossRef]

4. Devore, P.; Eyrand, C.; Prettre, M. Combustion du méthane et de l'hydrogène sur platine incandescent: Transfert d'énergie et mécanisme de la reaction. Comptes Rendus Acad. Sci. 1958, 246, 1200.

5. Firth, J.G.; Holland, H.B. Catalytic oxidation of methane over noble metals. Trans. Faraday Soc. 1969, 65, 1121-1127. [CrossRef]

6. Cullis, C.F.; Nevell, T.G.; Trimm, D.L. Role of the catalyst support in the oxidation of methane over palladium. J. Chem. Soc. Faraday Trans. 1972, 68, 1406-1412. [CrossRef]

7. McCarty, J.G.; Malukhin, G.; Poojary, D.M.; Datye, A.K.; Xu, Q. Thermal Coarsening of Supported Palladium Combustion Catalysts. J. Phys. Chem. B 2005, 109, 2387-2391. [CrossRef] [PubMed]

8. Farrauto, R.J. Low-Temperature Oxidation of Methane. Science 2012, 337, 659-660. [CrossRef]

9. Thirumalai, J. The Prominence of Thin Film Science in Technological Scale. In Thin Film Processes-Artifacts on Surface Phenomena and Technological Facets; Thirumalai, J., Ed.; IntechOpen, Open Research Library: London, UK, 2017.

10. Greene, J.E. Tracing the 5000-year recorded history of inorganic thin films from 3000 BC to the early 1900s AD. Appl. Phys. Rev. 2014, 1, 041302. [CrossRef]

11. Greene, J.E. Tracing the 4000-year recorded history of organic thin films: From monolayers on liquids to multilayers on solids. Appl. Phys. Rev. 2015, 2, 011101. [CrossRef]

12. Greene, J.E. Organic thin films: From monolayers on liquids to multilayers on solids. Phys. Today 2014, 67, 43. [CrossRef]

13. Lehner, M. The Complete Pyramids: Solving the Ancient Mysteries; Thames and Hudson, Ltd.: London, UK, 1997.

14. Baker, R.F.; Baker, C.F. Ancient Egyptians: People of the Pyramids; Oxford University: London, UK, 2001.

15. Ades, H. A Traveler's History of Egypt; Interlink Books: Northampton, MA, USA, 2007.

16. Harrell, J.A.; Brown, V.M. The world's oldest surviving geological map: The 1150 BC Turin papyrus from Egypt. J. Geol. 1992, 100, 3-18. [CrossRef] 
17. Harrell, J.A.; Brown, V.M. The oldest surviving topographical map from ancient Egypt (Turin Papyri 1879, 1899 and 1969). J. Am. Res. Cent. Egypt 1992, 29, 81-105. [CrossRef]

18. Notton, J.F.H. Ancient Egyptian gold refining. Gold Bull. 1974, 7, 50-56. [CrossRef]

19. Hunt, L.B. The oldest metallurgical handbook. Gold Bull. 1976, 9, 24-31. [CrossRef]

20. Zweibel, K. Thin films: Past, Present, Future. Natl. Tech. Inf. Serv. 1995, 3, 279-293.

21. James, T.G.H. Gold technology in ancient Egypt. Gold Bull. 1972, 5, 38-42. [CrossRef]

22. Darque-Ceretti, E.; Felder, E.; Aucouturier, M. Foil and leaf gilding on cultural artifacts; forming and adhesion. Rev. Mater. 2011, 16, 540-559. [CrossRef]

23. Lechtman, H. Pre-Columbian surface metallurgy. Sci. Am. 1984, 250, 56-63. [CrossRef]

24. Mallory, G.O.; Hajdu, J.B. Electroless Plating: Fundamentals and Applications; William Andrew Publishing: Norwich, NY, USA, 1990.

25. Ingo, G.M.; Guida, G.; Angelini, E.; Carlo, G.D.; Mezzi, A.; Padeletti, G. Ancient Mercury-Based Plating Methods: Combined Use of Surface Analytical Techniques for the Study of Manufacturing Process and Degradation Phenomena. Acc. Chem. Res. 2013, 46, 2365-2375. [CrossRef] [PubMed]

26. Brunetti, B.G.; Sgamellotti, A.; Clark, A.J. Advanced Techniques in Art Conservation. Acc. Chem. Res. 2010, 43, 693-694. [CrossRef]

27. Green, J.E. Tracing the recorded history of thin-film sputter deposition: From the 1800s to 2017. J. Vac. Sci. Technol. A 2017, 35, 05C204. [CrossRef]

28. Violi, I.L.; Zelcer, A.; Bruno, M.M.; Luca, V.; Soler-Illia, G.J.A.A. Gold Nanoparticles Supported in Zirconia-Ceria Mesoporous Thin Films: A Highly Active Reusable Heterogeneous Nanocatalyst. ACS Appl. Mater. Interfaces 2015, 7, 1114-1121. [CrossRef] [PubMed]

29. Di Valentin, C.; Del Vitto, A.; Pacchionni, G.; Abbet, S.; Worz, A.S.; Judai, K.; Heiz, U. Chemisorption and Reactivity of Methanol on MgO Thin Films. J. Phys. Chem. B 2002, 106, 11961-11969. [CrossRef]

30. Klaus, S.; Louie, M.W.; Trotochaud, L.; Bell, A.T. Role of Catalyst Preparation on the Electrocatalytic Activity of $\mathrm{Ni}_{1-\mathrm{x}} \mathrm{Fe}_{\mathrm{x}} \mathrm{OOH}$ for the Oxygen Evolution Reaction. J. Phys. Chem. C 2015, 119, 18303-18316. [CrossRef]

31. Belton, D.N.; Sun, Y.M.; White, J.M. Thin-Film Models of Strong Metal-Support Interaction Catalysts. Platinum on Oxidized Titanium. J. Phys. Chem. 1984, 88, 1690-1695. [CrossRef]

32. Miller, E.L.; Rocheleau, R.E. Electrochemical Behavior of Reactively Sputtered Iron-Doped Nickel Oxide. J. Electrochem. Soc. 1997, 144, 3072-3077. [CrossRef]

33. Corrigan, D.A. The Catalysis of the Oxygen Evolution Reaction by Iron Impurities in Thin-Film Nickel-Oxide Electrodes. J. Electrochem. Soc. 1987, 134, 377-384. [CrossRef]

34. Cooper, V.R.; Kolpak, A.M.; Yourdshahyan, Y.; Rappe, A.M. Oxide supported metal thin film catalysts: The how and why. In Nanotechnology in Catalysis; Springer: New York, NY, USA, 2007; pp. 13-21.

35. Ischenko, O.; Krishnamoorthya, S.; Valle, N.; Guillot, J.; Turek, P.; Fechete, I.; Lenoble, D. Investigating vapor phase growth of block copolymer templated titania nanoarrays. J. Phys. Chem. C 2016, 120, 7067-7076. [CrossRef]

36. Stoian, M.; Rogé, V.; Lazar, L.; Maurer, T.; Védrine, J.C.; Marcu, I.C.; Fechete, I. Total Oxidation of Methane on Oxide and Mixed Oxide Ceria-Containing Catalysts. Catalysts 2021, 11, 427. [CrossRef]

37. Stoerzinger, K.A.; Choi, W.S.; Jeen, H.; Lee, H.N.; Shao-Horn, Y. Role of Strain and Conductivity in Oxygen Electrocatalysis on $\mathrm{LaCoO}_{3}$ Thin Films. J. Phys. Chem. Lett. 2015, 6, 487-492. [CrossRef]

38. Olayinka, O.A.; Akinlabi, E.; Oladijo, P.; Akinlabi, S.; Ude, A.U. Overview of thin film deposition techniques. AIMS Mater. Sci. 2019, 6, 174-199. [CrossRef]

39. Mattox, D.M. Handbook of Physical Vapor Deposition (PVD) Processing; William Andrew Publishing: Norwich, NY, USA, 2010.

40. Wasa, K.; Kitabatake, M.; Adachi, H. Thin Film Materials Technology: Sputtering of Control Compound Materials; Springer Science \& Business Media: New York, NY, USA, 2004.

41. Lewis, B.L.; Anderson, J.C. Nucleation and Growth of Thin Films; Academic Press: New York, NY, USA, 1978.

42. Venables, J.A.; Spiller, G.D.T. Nucleation and growth of thin films. In Surface Mobilities on Solid Materials; Binh, V.T., Ed.; Springer: Boston, MA, USA, 1983; Volume 3, pp. 341-404.

43. Lewis, B.; Campbell, D. Nucleation and initial-growth behavior of thin-film deposits. J. Vac. Sci. Technol. 1967, 4, 209-218. [CrossRef]

44. Lane, G.E.; Anderson, J.C. The nucleation and initial growth of gold films deposited onto sodium chloride by ion-beam sputtering. Thin Solid Films 1975, 26, 5-23. [CrossRef]

45. Martin, P. Introduction to Surface Engineering and Functionally Engineered Materials; Wiley-Scrivener: Beverly, MA, USA, 2011.

46. Seshan, K. Handbook of Thin Film Deposition, 3rd ed.; William Andrew Publishing: Norwich, NY, USA, 2012.

47. West, A.R. Solid State Chemistry and Its Applications, 2nd ed.; John Wiley \& Sons: Singapore, 2014.

48. Chopra, K.L. Thin Film Phenomena, 1st ed.; McGraw Hill: New York, NY, USA, 1969.

49. Kelly, P.; Arnell, R. Magnetron sputtering: A review of recent developments and applications. Vacuum 2000, 56, 159-172. [CrossRef]

50. Kelly, P.; Arnell, R.; Ahmed, W. Some recent applications of materials deposited by unbalanced magnetron sputiering. Surf. Eng. 1993, 9, 287-292. [CrossRef]

51. Stokes, J. Production of Coated and Free-Standing Engineering Components Using the HVOF (High Velocity Oxy-Fuel) Process. Ph.D. Thesis, Dublin City University, Dublin, Ireland, 2003. 
52. Panjan, P.; Drnovšek, A.; Gselman, P.; Cekada, M.; Panjan, M. Review of Growth Defects in Thin Films Prepared by PVD Techniques. Coatings 2020, 10, 447. [CrossRef]

53. Trajkovska-Petkoska, A.; Nasov, I. Surface engineering of polymers: Case study: PVD coatings on polymers. Zast. Mater. 2014, 55, 3-10. [CrossRef]

54. Cao, G. Nanostructures and Nanomaterials: Synthesis, Properties and Applications, 2nd ed.; Imperial College Press: London, UK, 2004.

55. Messier, M.; Giri, A.P.; Roy, R.A. Revised structure zone model for thin film physical structure. J. Vac. Sci. Technol. A 1983, 2, 500-503. [CrossRef]

56. Ricciardi, S. Surface Chemical Functionalization Based on Plasma Techniques; Lambert Academics Publishing: Sunnyvale, CA, USA, 2012.

57. Mattox, D.M. Atomistic Film Growth and Some Growth-Related Film Properties. In Handbook of Physical Vapor Deposition (PVD) Processing; William Andrew: Norwich, NY, USA, 1998; ISBN 978-0-8155-1422-0.

58. Herman, M.A.; Sitter, H. Molecular Beam Epitaxy: Fundamentals and Current Status; Springer Science \& Business Media: New York, NY, USA, 2012.

59. Chen, Y.; Bagnall, D.; Koh, H.; Park, K.-T.; Hiraga, K.; Zhu, Z.; Yao, T. Plasma assisted molecular beam epitaxy of ZnO on c-plane sapphire: Growth and characterization. J. Appl. Phys. 1998, 84, 3912-3918. [CrossRef]

60. Rinaldi, F. Basics of Molecular Beam Epitaxy (MBE). Annual Report 2002; Optoelectronics Department, University of Ulm: Ulm, Germany, 2002; pp. 1-8.

61. Cho, A.Y.; Reinhart, F.K. MBE Technique for Fabricating Semiconductor Devices Having Low Series Resistance. U.S. Patent US 3915765 A, 28 October 1975.

62. Mergel, D.; Buschendorf, D.; Eggert, S.; Grammes, R.; Samset, B. Density and refractive index of $\mathrm{TiO}_{2}$ films prepared by reactive evaporation. Thin Solid Films 2000, 371, 218-224. [CrossRef]

63. Pulker, H.K.; Paesold, G.; Ritter, E. Refractive indices of $\mathrm{TiO}_{2}$ films produced by reactive evaporation of various titanium-oxygen phases. Appl. Opt. 1976, 15, 2986-2991. [CrossRef]

64. Terashima, T.; Iijima, K.; Yamamoto, K.; Bando, Y.; Mazaki, H. Single-crystal $\mathrm{YBa}_{2} \mathrm{Cu}_{3} \mathrm{O}_{7-\mathrm{x}}$ thin films by activated reactive evaporation. Jpn. J. Appl. Phys. 1988, 27, L91. [CrossRef]

65. Bunshah, R.; Raghuram, A. Activated reactive evaporation process for high rate deposition of compounds. J. Vac. Sci. Technol. 1972, 9, 1385-1388. [CrossRef]

66. Bunshah, R. The activated reactive evaporation process: Developments and applications. Thin Solid Films 1981, 80, $255-261$. [CrossRef]

67. Wasa, K.; Hayakawa, S. Handbook of Sputter Deposition Technology; Noyes Publications: Park Ridge, NJ, USA, 1992.

68. Wasa, K.; Kitabatake, M.; Adachi, H. Thin Film Processes. In Thin Film Materials Technology; Wasa, K., Kitabatake, M., Adachi, H., Eds.; William Andrew Publishing: Norwich, NY, USA, 2004; pp. 17-69.

69. Baragiola, R.A. Sputtering: Survey of observations and derived principles. Philos. Trans. R. Soc. Lond. Ser. A Math. Phys. Eng. Sci. 2004, 362, 29-53. [CrossRef]

70. Musil, J.; Baroch, P.; Vlcek, J.; Nam, K.H.; Han, J.G. Reactive magnetron sputtering of thin films: Present status and trends. Thin Solid Films 2005, 475, 208-218. [CrossRef]

71. Safi, I. Recent aspects concerning DC reactive magnetron sputtering of thin films: A review. Surf. Coat. Technol. 2000, 127, 203-219. [CrossRef]

72. Leydecker, S. Nano Materials. In Architecture, Interior Architecture and Design; Springer Science and Business Media: Birkhauser, Switzerland, 2008; ISBN 3764379952.

73. Phillips, R.W.; Raksha, V. Methods for Producing Enhanced Interference Pigments. U.S. Patent US 6524381 B2, 25 February 2003.

74. Schultz, P.G.; Xiang, X.; Goldwasser, I.; Briceno, G.; Sun, X.-D.; Wang, K.-A. Combinatorial Synthesis and Screening of NonBiological Polymers. U.S. Patent US 7034091, 25 April 2006.

75. Seyfert, U.; Heisig, U.; Teschner, G. 40 Years of Industrial Magnetron Sputtering in Europe. SVC Bull. Fall 2015, $22-26$.

76. Seshan, K. Handbook of Thin-Film Deposition Processes and Techniques, Principles, Methods, Equipment and Applications; Noyes Publications/William Andrew Publishing: Norwich, NY, USA, 2001.

77. Teixeira, V.; Cui, H.; Meng, L.; Fortunato, E.; Martins, R. Amorphous ITO thin films prepared by DC sputtering for electrochromic applications. Thin Solid Films 2002, 420, 70-75. [CrossRef]

78. Utsumi, K.; Iigusa, H.; Tokumaru, R.; Song, P.K.; Shigesato, Y. Study on $\mathrm{In}_{2} \mathrm{O}_{3}-\mathrm{SnO}_{2}$ transparent and conductive films prepared by d.c. sputtering using high density ceramic targets. Thin Solid Films 2003, 445, 229-234. [CrossRef]

79. Gómez, A.; Galeano, A.; Saldarriaga, W.; Arnache, O.; Moran, O. Deposition of $\mathrm{YBaCo}_{4} \mathrm{O}_{7+\delta}$ thin films on (001)-SrTiO $\mathrm{S}_{3}$ substrates by dc sputtering. Vacuum 2015, 119, 7-14. [CrossRef]

80. Cash, J.H., Jr.; Cunningham, J.A. Rf Sputtering Method. U.S. Patent 3677924, 18 July 1972.

81. You, T.; Niwa, O.; Tomita, M.; Ando, H.; Suzuki, M.; Hirono, S. Characterization and electrochemical properties of highly dispersed copper oxide/hydroxide nanoparticles in graphite-like carbon films prepared by RF sputtering method. Electrochem. Commun. 2002, 4, 468-471. [CrossRef]

82. Torng, C.; Sivertsen, J.M.; Judy, J.H.; Chang, C. Structure and bonding studies of the C: N thin films produced by rf sputtering method. J. Mater. Res. 1990, 5, 2490-2496. [CrossRef] 
83. Constantin, D.G.; Apreutesei, M.; Arvinte, R.; Marin, A.; Andrei, O.C.; Munteanu, D. Magnetron sputtering technique used for coatings deposition; technologies and applications. In Proceedings of the 7th International Conference on Materials Science and Engineering-BRAMAT 2011, Brasov, Romania, 24-26 February 2011.

84. David, J.C. Making Magnetron Sputtering Work: Modelling Reactive Sputtering Dynamics, Part 1. SVC Bull. Fall 2015, 28-32.

85. Arnell, R.D.; Kelly, P.J. Recent advances in magnetron sputtering. Surf. Coat. Tech. 1999, 112, 170-176. [CrossRef]

86. Musil, J. Recent advances in magnetron sputtering technology. Surf. Coat. Tech. 1998, 100, 280-286. [CrossRef]

87. Suzuki, Y.; Teranishi, K. Reactive Sputtering Method. U.S. Patent 7575661B2, 18 August 2009.

88. Ishihara, M.; Li, S.; Yumoto, H.; Akashi, K.; Yde, Y. Control of preferential orientation of AlN films prepared by the reactive sputtering method. Thin Solid Films 1998, 316, 152-157. [CrossRef]

89. Chistyakov, R. High-Power Pulsed Magnetron Sputtering. U.S. Patent 7147759B2, 12 December 2006.

90. Kouznetsov, V.; Macák, K.; Schneider, J.M.; Helmersson, U.; Petrov, I. A novel pulsed magnetron sputter technique utilizing very high target power densities. Surf. Coat. Tech. 1999, 122, 290-293. [CrossRef]

91. Sarakinos, K.; Alami, J.; Konstantinidis, S. High power pulsed magnetron sputtering: A review on scientific and engineering state of the art. Surf. Coat. Tech. 2010, 204, 1661-1684. [CrossRef]

92. Alami, J.; Bolz, S.; Sarakinos, K. High power pulsed magnetron sputtering: Fundamentals and applications. J. Alloys Compd. 2009, 483, 530-534. [CrossRef]

93. Wu, X.; Toe, C.-Y.; Su, C.; Ng, Y.-H.; Amal, R.; Scott, J. Preparation of Bi-based photocatalysts in the form of powdered particles and thin films: A review. J. Mater. Chem. A 2020, 8, 15302-15318. [CrossRef]

94. Carlsson, J.; Martin, P.M. Chemical Vapor Deposition. In Handbook of Deposition Technologies for Films and Coatings: Science, Applications and Technology, 3rd ed.; Martin, P.M., Ed.; William Andrew Publishing: Boston, MA, USA, 2010; Chapter 7; pp. $314-363$.

95. Albetran, H.M.M. Synthesis and Characterisation of Nanostructured $\mathrm{TiO}_{2}$ for Photocatalytic Applications. Ph.D. Thesis, Curtin University, Perth, WA, Australia, 2016.

96. Miller, T. An Investigation into the Growth and Characterisation of Thin Film Radioluminescent Phosphors for Neutron Diffraction Analysis. Ph.D. Thesis, Nottingham Trent University, Nottingham, UK, 2010.

97. Pessoa, R.; Fraga, M.; Santos, L. Nanostructured thin films based on $\mathrm{TiO}_{2}$ and/or $\mathrm{SiC}$ for use in photoelectrochemical cells: A review of the material characteristics, synthesis and recent applications. Mat. Sci. Semicon. Proc. 2015, 29, 56-68. [CrossRef]

98. Kommu, S.; Wilson, G.M.; Khomami, B. A Theoretical/Experimental Study of Silicon Epitaxy in Horizontal Single-Wafer Chemical Vapor Deposition Reactors. J. Electrochem. Soc. 2000, 147, 1538-1550. [CrossRef]

99. Pedersen, H.; Elliott, S.D. Studying chemical vapor deposition processes with theoretical chemistry. Theor. Chem. Acc. 2014, $133,1476$. [CrossRef]

100. Wang, D.N.; White, J.M.; Law, K.S.; Leung, C.; Umotoy, S.P.; Collins, S.K.; Adamik, J.A.; Perlov, I.; Maydan, D. Thermal CVD/PECVD reactor and Use for Thermal Chemical Vapor Deposition of Silicon Dioxide and In-Situ Multi-Step Planarized Process. U.S. Patent 5000113, 19 March 1991.

101. Hirose, Y.; Terasawa, Y. Synthesis of diamond thin films by thermal CVD using organic compounds. Jpn. J. Appl. Phys. 1986, 25, L519. [CrossRef]

102. Petzoldt, F.; Piglmayer, K.; Kräuter, W.; Bauerele, D. Lateral growth rates in laser CVD of microstructures. Appl. Phys. A 1984, 35, 155-159. [CrossRef]

103. Sousa, P.; Silvestre, A.; Popovici, N.; Conde, O. Morphological and structural characterization of $\mathrm{CrO}_{2} / \mathrm{Cr}_{2} \mathrm{O}_{3}$ films grown by Laser-CVD. Appl. Surf. Sci. 2005, 247, 423-428. [CrossRef]

104. Matsui, S. Three-dimensional nanostructure fabrication by focused-ion-beam chemical vapor deposition. J. Vac. Sci. Technol. B 2000, 18, 3181-3184. [CrossRef]

105. Inoue, K.; Michimori, M.; Okuyama, M.; Hamakawa, Y. Low temperature growth of $\mathrm{SiO}_{2}$ thin film by double-excitation photo-CVD. Jpn. J. Appl. Phys. 1987, 26, 805. [CrossRef]

106. Tanimoto, S.; Matsui, M.; Kamisako, K.; Kuroiwa, K.; Tarui, Y. Investigation on leakage current reduction of photo-CVD tantalum oxide films accomplished by active oxygen annealing. J. Electrochem. Soc. 1992, 139, 320-328. [CrossRef]

107. Price, J.; Wu, S. Plasma Enhanced CVD. U.S. Patent 4692343, 8 September 1987.

108. Li, Y.; Mann, D.; Rolandi, M.; Kim, W.; Ural, A.; Hung, S.; Javey, A.; Cao, J.; Wang, D.; Yenilmez, E.; et al. Preferential growth of semiconducting single-walled carbon nanotubes by a plasma enhanced CVD method. Nano Lett. 2004, 4, 317-321. [CrossRef]

109. Hozumi, A.; Takai, O. Preparation of ultra water-repellent films by microwave plasma-enhanced CVD. Thin Solid Films 1997, 303, 222-225. [CrossRef]

110. Graniel, O.; Weber, M.; Balme, S.; Miele, P.; Bechelany, M. Atomic layer deposition for biosensing applications. Biosens. Bioelectron. 2018, 122, 147-159. [CrossRef] [PubMed]

111. Suntola, T.; Antson, J. Method for Producing Compound Thin Films. U.S. Patent 4058430, 15 November 1977.

112. Guo, H.C.; Ye, E.; Li, Z.; Han, M.-Y.; Loh, X.J. Recent progress of atomic layer deposition on polymeric materials. Mat. Sci. Eng. C Mater. 2017, 70, 1182-1191. [CrossRef] [PubMed]

113. George, S.M. Atomic layer deposition: An overview. Chem. Rev. 2009, 110, 111-131. [CrossRef] [PubMed]

114. Miikkulainen, V.; Leskelä, M.; Ritala, M.; Puurunen, L.R. Crystallinity of inorganic films grown by atomic layer deposition: Overview and general trends. J. Appl. Phys. 2013, 113, 2. [CrossRef]

115. Bohr, M.T.; Chau, R.S.; Ghani, T.; Mistry, K. The high-k solution. IEEE Spectr. 2007, 44, 29-35. [CrossRef] 
116. Yan, B.; Li, X.; Bai, Z.; Song, X.; Xiong, D.; Zhao, M.; Li, D.; Lu, S. A review of atomic layer deposition providing high performance lithium sulfur batteries. J. Power Sources 2017, 338, 34-48. [CrossRef]

117. Ozer, N.; Lampert, C.M. Electrochromic characterization of sol-gel deposited coatings. Sol. Energy Mater. Sol. Cells 1998, 54, 147-156. [CrossRef]

118. Niinisto, L.; Ritala, M.; Leskela, M. Synthesis of oxide thin films and overlayers by atomic layer epitaxy for advanced applications. Mater. Sci. Eng. B 1996, 41, 23-29. [CrossRef]

119. Kim, H.; Lee, H.B.R.; Maeng, W.-J. Applications of atomic layer deposition to nanofabrication and emerging nanodevices. Thin Solid Films 2009, 517, 2563-2580. [CrossRef]

120. Knez, M.; Nielsch, K.; Niinistö, L. Synthesis and Surface Engineering of Complex Nanostructures by Atomic Layer Deposition. Adv. Mater. 2007, 19, 3425-3438. [CrossRef]

121. Szilágyi, I.M.; Nagy, D. Review on one-dimensional nanostructures prepared by electrospinning and atomic layer deposition. J. Phys. Conf. Ser. 2014, 559, 012010. [CrossRef]

122. Devi, A. "Old Chemistries" for new applications: Perspectives for development of precursors for MOCVD and ALD applications. Coord. Chem. Rev. 2013, 257, 3332-3384. [CrossRef]

123. Puurunen, R.L. A short history of atomic layer deposition: Tuomo Suntola's atomic layer epitaxy. Chem. Vap. Depos. 2014, 20, 332-344. [CrossRef]

124. Malygin, A.A.; Drozd, V.E.; Malkov, A.A.; Smirnov, V.M. From VB Aleskovskii's "Framework" Hypothesis to the Method of Molecular Layering/Atomic Layer Deposition. Chem. Vap. Depos. 2015, 21, 216-240. [CrossRef]

125. Leskelä, M.; Ritala, M. Atomic layer deposition (ALD): From precursors to thin film structures. Thin Solid Films 2002, 409, 138-146. [CrossRef]

126. Chalker, P. Photochemical atomic layer deposition and etching. Surf. Coat. Technol. 2016, 291, 258-263. [CrossRef]

127. Leskelä, M.; Ritala, M. Atomic Layer Deposition Chemistry: Recent Developments and Future Challenges. Angew. Chem. Int. Ed. Engl. 2003, 42, 5548-5554. [CrossRef] [PubMed]

128. Ritala, M.; Leskelä, M. Atomic layer deposition. In Handbook of Thin Film Materials Volume 1: Deposition and Processing of Thin Films; Elsevier: Amsterdam, The Netherlands, 2002; Volume 1, pp. 103-159.

129. Aaltonen, T.; Ritala, M.; Tung, Y.-L.; Chi, Y.; Arstila, K.; Meinander, K.; Leskela, M. Atomic layer deposition of noble metals: Exploration of the low limit of the deposition temperature. J. Mater. Res. 2004, 19, 3353-3358. [CrossRef]

130. Johnson, R.W.; Hultqvist, A.; Bent, S.F. A brief review of atomic layer deposition: From fundamentals to applications. Mater. Today 2014, 17, 236-246. [CrossRef]

131. Lim, B.S.; Rahtu, A.; Gordon, R.G. Atomic layer deposition of transition metals. Nat. Mater. 2003, 2, 749-754. [CrossRef] [PubMed]

132. Weber, M.J.; Mackus, J.M.A.; Verheijen, A.M.; Longo, V.; Bol, A.A.; Kessels, M.M.W. Atomic layer deposition of high-purity palladium films from $\mathrm{Pd}(\mathrm{hfac}) 2$ and $\mathrm{H}_{2}$ and $\mathrm{O}_{2}$ Plasmas. J. Phys. Chem. C 2014, 118, 8702-8711. [CrossRef]

133. Hämäläinen, J.; Ritala, M.; Leskelä, M. Atomic Layer Deposition of Noble Metals and Their Oxides. Chem. Mater. 2014, 26, 786-801. [CrossRef]

134. Kim, H. Atomic layer deposition of metal and nitride thin films: Current research efforts and applications for semiconductor device processing. J. Vac. Sci. Technol. B 2003, 21, 2231. [CrossRef]

135. Weber, M.; Koonkaew, B.; Balme, S.; Utke, I.; Picaud, F.; Iatsunskyi, I.; Coy, E.; Miele, P.; Bechelany, M. Boron nitride nanoporous membranes with high surface charge by atomic layer deposition. ACS Appl. Mater. Interfaces 2017, 9, 16669-16678. [CrossRef]

136. Meng, X.; Cao, Y.; Libera, A.J.; Elam, W.J. Atomic Layer Deposition of Aluminum Sulfide: Growth Mechanism and Electrochemical Evaluation in Lithium-Ion Batteries. Chem. Mater. 2017, 29, 9043-9052. [CrossRef]

137. Peters, A.W.; Li, Z.; Farha, O.K.; Hupp, J.T. Atomically Precise Growth of Catalytically Active Cobalt Sulfide on Flat Surfaces and within a Metal-Organic Framework via Atomic Layer Deposition. ACS Nano 2015, 9, 8484-8490. [CrossRef]

138. Gong, Y.; Palacio, D.; Song, X.; Patel, L.R.; Liang, X.; Zhao, X.; Goodenough, J.B.; Huang, K. Stabilizing Nanostructured Solid Oxide Fuel Cell Cathode with Atomic Layer Deposition. Nano Lett. 2013, 13, 4340-4345. [CrossRef]

139. Hong, Y.; Kim, C.-H.; Shin, J.; Kim, K.Y.; Kim, J.S.; Hwang, C.S.; Lee, J.-H. Highly selective ZnO gas sensor based on MOSFET having a horizontal floating-gate. Sens. Actuators B Chem. 2016, 232, 653-659. [CrossRef]

140. Ho, T.A.; Bae, C.; Nam, H.; Kim, E.; Lee, S.Y.; Park, J.H.; Shin, H. Metallic $\mathrm{Ni}_{3} \mathrm{~S}_{2}$ Films Grown by Atomic Layer Deposition as an Efficient and Stable Electrocatalyst for Overall Water Splitting. ACS Appl. Mater. Interfaces 2018, 10, 12807-12815. [CrossRef]

141. Weber, M.; Iatsunskyi, Y.; Coy, E.; Miele, P.; Cornu, D.; Bechelany, M. Novel and Facile Route for the Synthesis of Tunable Boron Nitride Nanotubes Combining Atomic Layer Deposition and Annealing Processes for Water Purification. Adv. Mater. Interfaces 2018, 5, 1800056. [CrossRef]

142. Black, A.; Urbanos, F.J.; Osorio, M.R.; Miranda, R.; Vázquez de Parga, A.L.; Granados, D. Encapsulating Chemically Doped Graphene via Atomic Layer Deposition. ACS Appl. Mater. Interfaces 2018, 10, 8190-8196. [CrossRef]

143. Weber, M.; Julbe, A.; Kim, S.S. Atomic layer deposition (ALD) on inorganic or polymeric membranes. J. Appl. Phys. 2019, $126,041101$. [CrossRef]

144. Elias, J.; Bechelany, M.; Utke, I.; Erni, R.; Hosseini, D.; Michler, J.; Philippe, L. Urchin-inspired zinc oxide as building blocks for nanostructured solar cells. Nano Energy 2012, 1, 696-705. [CrossRef]

145. Van Delft, J.A.; Garcia-Alonso, D.; Kessels, W.M.M. Atomic layer deposition for photovoltaics: Applications and prospects for solar cell manufacturing. Semicond. Sci. Technol. 2012, 27, 074002. [CrossRef] 
146. Tian, Z.Y.; Bahlawane, N.; Vannier, V.; Kohse-Höinghaus, K. Structure sensitivity of propene oxidation over Co-Mn spinels. Proc. Combust. Inst. 2013, 34, 2261-2268. [CrossRef]

147. Bahlawane, N.; Premkumar, P.A.; Tian, Z.Y.; Hong, X.; Qi, F.; Kohse-Höinghaus, K. Nickel and nickel-based nanoalloy thin films from alcohol-assisted chemical vapor deposition. Chem. Mater. 2010, 22, 92-100. [CrossRef]

148. Mountapmbeme, K.P.; Tian, Z.Y.; Mundloch, U.; Bahlawane, N.; Kohseo-Höinghaus, K. Controlled synthesis of $\mathrm{Co}_{3} \mathrm{O}_{4}$ spinel with $\mathrm{Co}(\mathrm{acac})_{3}$ as precursor. RSC Adv. 2012, 2, 10809-10812.

149. Ngamou, P.H.T.; Bahlawane, N. Influence of the Arrangement of the Octahedrally Coordinated Trivalent Cobalt Cations on the Electrical Charge Transport and Surface Reactivity. Chem. Mater. 2010, 22, 4158-4165.

150. Premkumar, P.A.; Bahlawane, N.; Kohse-Höinghaus, K. CVD of metals using alcohols and metal acetylacetonates, Part I: Optimization of process parameters and electrical characterization of synthesized films. Chem. Vap. Depos. 2007, 13, 219-226. [CrossRef]

151. Weiss, T.; Nowak, M.; Mundloch, U.; Zielasek, V.; Kohse-Hoinghaus, K.; Baumer, M. Design of a compact ultrahigh vacuumcompatible setup for the analysis of chemical vapor deposition processes. Rev. Sci. Instrum. 2015, 85, 104104. [CrossRef]

152. Shrestha, S.; Hutchins, S.; Dunkin, O.; Curran, J.; Wagner, R. Recent Developments in Black Finish Coatings on Aluminum Alloys by Keronite Plasma Electrolytic Oxidation in Engine, Transmission, Propulsion and Emission; Global Powertrain Congress: Saline, MI, USA, 2007; Volume 39-42, pp. 207-215.

153. Mistry, K.; Priest, M.; Shrestha, S. The potential of plasma electrolytic oxidized eutectic aluminium-silicon alloy as a cylinder wall surface for lightweight engine blocks. Proc. Inst. Mech. Eng. Part J-J. Eng. Tribol. 2010, 224, 221-229. [CrossRef]

154. Stojadinović, S.; Vasilic, R.; Radic, N.; Tadic, N.; Stefanov, P.; Grbic, B. The formation of tungsten doped Al2O3/ZnO coatings on aluminum by plasma electrolytic oxidation and their application in photocatalysis. Appl. Surf. Sci. 2016, 377, 37-43. [CrossRef]

155. Friedemann, A.E.R.; Thiel, K.; Gesing, T.M.; Plagemann, P. Photocatalytic activity of $\mathrm{TiO}_{2}$ layers produced with plasma electrolytic oxidation. Surf. Coat. Technol. 2018, 344, 710-721. [CrossRef]

156. Yerokhin, A.L.; Lyubimov, V.V.; Ashitkov, R.V. Phase formation in ceramic coatings during plasma electrolytic oxidation of aluminium alloys. Ceram. Int. 1988, 24, 1-6. [CrossRef]

157. Klapkiv, M.D.; Nykyforchyn, H.M.; Posuvailo, V.M. Spectral analysis of an electrolytic plasma in the process of synthesis of aluminum oxide. Mater. Sci. 1995, 30, 333-343. [CrossRef]

158. Klapkiv, M.D. Simulation of synthesis of oxide-ceramic coatings in discharge channels of a metaloelectrolyte system. Mater. Sci. 1999, 35, 279-283. [CrossRef]

159. Klapkiv, M.D.; Chuchmarev, O.S.; Sydor, P.Y.; Posuvailo, V.M. Thermodynamics of the interaction of aluminum, magnesium, and zirconium with components of an electrolytic plasma. Mater. Sci. 2000, 36, 66-79. [CrossRef]

160. Dunleavy, C.S.; Golosnoy, I.O.; Curran, J.A.; Clyne, T.W. Characterisation of discharge events during plasmaelectrolytic oxidation. Surf. Coat. Technol. 2009, 203, 3410-3419. [CrossRef]

161. Matykina, E.; Arrabal, R.; Skeldon, P.; Thompson, G.E.; Belenguer, P. AC PEO of aluminium with porous alumina precursor films. Surf. Coat. Technol. 2010, 205, 1668-1678. [CrossRef]

162. Matykina, E.; Arrabal, R.; Skeldon, P.; Thompson, G.E. Incorporation of zirconia nanoparticles into coatings formed on aluminium by AC plasma electrolytic oxidation. J. Appl. Electrochem. 2008, 38, 1375-1383. [CrossRef]

163. Arrabal, R.; Matykina, E.; Viejo, F.; Skeldon, P.; Thompson, G.E.; Merino, M.C. AC plasma electrolytic oxidation of magnesium with zirconia nanoparticles. Appl. Surf. Sci. 2008, 254, 6937-6942. [CrossRef]

164. Yerokhin, A.L.; Nie, X.; Leyland, A.; Matthews, A.; Dowey, S.J. Plasma electrolysis for surface engineering. Surf. Coat. Technol. 1999, 122, 73-93. [CrossRef]

165. Kuhn, A. Plasma anodizing of magnesium alloys. Metal. Finish. 2003, 101, 44-50. [CrossRef]

166. McPherson, R. Formation of metastable phases in flame- and plasma-prepared alumina. J. Mater. Sci. 1973, 8, 851-858. [CrossRef]

167. Jiang, B.L.; Wang, Y.M. 5-Plasma electrolytic oxidation treatment of aluminium and titanium alloys. In Surface Engineering of Light Alloys; Dong, H., Ed.; Woodhead Publishing Series in Metals and Surface, Engineering; Woodhead Publishing: Sawston, UK, 2010; pp. 110-154.

168. Rogov, A.B.; Yerokhin, A.; Matthews, A. The Role of Cathodic Current in Plasma Electrolytic Oxidation of Aluminum: Phenomenological Concepts of the "Soft Sparking" Mode. Langmuir 2017, 33, 11059-11069. [CrossRef]

169. Timoshenko, A.V.; Magurova, Y.V. Investigation of plasma electrolytic oxidation processes of magnesium alloy MA2-1 under pulse polarisation modes. Surf. Coat. Technol. 2005, 199, 135-140. [CrossRef]

170. Farrauto, R.J.; Hobson, M.C.; Kennelly, T.; Waterman, E.M. Catalytic chemistry of supported palladium for combustion of methane. Appl. Catal. A Gen. 1992, 81, 227-237. [CrossRef]

171. Adijanto, L.; Bennett, D.A.; Chen, C.; Yu, A.S.; Cargnello, M.; Fornasiero, P.; Gorte, R.J.; Vohs, J.M. Exceptional Thermal Stability of Pd@CeO 2 Core-Shell Catalyst Nanostructures Grafted onto an Oxide Surface. Nano Lett. 2013, 13, 2252-2257. [CrossRef] [PubMed]

172. Chen, C.; Yeh, Y.; Cargnello, M.; Murray, C.B.; Fornasiero, P.; Gorte, R.J. Methane Oxidation on Pd@ $\mathrm{ZrO}_{2} / \mathrm{Si}-\mathrm{Al}_{2} \mathrm{O}_{3} \mathrm{Is}$ Enhanced by Surface Reduction of $\mathrm{ZrO}_{2}$. ACS Catal. 2014, 4, 3902-3909. [CrossRef]

173. Colussi, S.; Gayen, A.; Camellone, M.F.; Boaro, M.; Llorca, J.; Fabris, S.; Trovarelli, A. Nanofaceted Pd-O sites in Pd-Ce surface superstructures: Enhanced activity in catalytic combustion of methane. Angew. Chem. Int. Ed. 2009, 48, 8481-8484. [CrossRef] 
174. Cargnello, M.; Jaén, J.D.; Garrido, J.H.; Bakhmutsky, K.; Montini, T.; Gámez, J.C.; Gorte, R.J.; Fornasiero, P. Exceptional activity for methane combustion over modular $\mathrm{Pd} @ \mathrm{CeO}_{2}$ subunits on functionalized $\mathrm{Al}_{2} \mathrm{O}_{3}$. Science 2012, 337, 713-717. [CrossRef]

175. Ciuparu, D.; Lyubovsky, M.R.; Altman, E.; Pfefferle, L.D.; Datye, A. Catalytic combustion of methane over palladium-based catalysts. Catal. Rev. Sci. Eng. 2002, 44, 593-649. [CrossRef]

176. Forzatti, P.; Lietti, L. Catalyst deactivation. Catal. Today 1999, 52, 165-181. [CrossRef]

177. Monai, M.; Montini, T.; Chen, C.; Fonda, E.; Gorte, R.J.; Fornasiero, P. Methane Catalytic Combustion over Hierarchical $\mathrm{Pd} @ \mathrm{CeO}_{2} / \mathrm{Si}_{-} \mathrm{Al}_{2} \mathrm{O}_{3}$ : Effect of the Presence of Water. Chem. Cat. Chem. 2015, 7, 2038-2046. [CrossRef]

178. O'Neill, B.J.; Jackson, D.H.K.; Lee, J.; Canlas, C.; Stair, P.C.; Marshall, C.L.; Elam, J.W.; Kuech, T.F.; Dumesic, J.A.; Huber, G.W. Catalyst design with atomic layer deposition. ACS Catal. 2015, 5, 1804-1825. [CrossRef]

179. O'Neill, B.J.; Jackson, D.H.K.; Crisci, A.J.; Farberow, C.A.; Shi, F.; Alba-Rubio, A.C.; Lu, J.; Dietrich, P.J.; Gu, X.; Marshall, C.L.; et al. Stabilization of copper catalysts for liquid-phase reactions by atomic layer deposition. Angew. Chem. Int. Ed. 2013, 52, 13808-13812. [CrossRef] [PubMed]

180. Lu, J.; Fu, B.; Kung, M.C.; Xiao, G.; Elam, J.W.; Kung, H.H.; Stair, P.C. Coking- and sintering-resistant palladium catalysts achieved through atomic layer deposition. Science 2012, 335, 1205-1208. [CrossRef]

181. Gould, T.D.; Izar, A.; Weimer, A.W.; Falconer, J.L.; Medlin, J.W. Stabilizing Ni catalysts by molecular layer deposition for harsh, dry reforming conditions. ACS Catal. 2014, 4, 2714-2717. [CrossRef]

182. Onn, T.M.; Zhang, S.; Arroyo-Ramirez, L.; Chung, Y.C.; Graham, G.W.; Pan, X.; Gorte, R.J. Improved Thermal Stability and Methane-Oxidation Activity of $\mathrm{Pd} / \mathrm{Al}_{2} \mathrm{O}_{3}$ Catalysts by Atomic Layer Deposition of $\mathrm{ZrO}_{2}$. ACS Catal. 2015, 5, 5696-5701. [CrossRef]

183. Pramhaas, V.; Roiaz, M.; Bosio, N.; Corva, M.; Rameshan, C.; Vesselli, E.; Grönbeck, H.; Rupprechter, G. Interplay between CO Disproportionation and Oxidation: On the Origin of the $\mathrm{CO}$ Reaction Onset on Atomic Layer Deposition-Grown $\mathrm{Pt} / \mathrm{ZrO} 2 \mathrm{Model}$ Catalysts. ACS Catal. 2021, 11, 208-214. [CrossRef] [PubMed]

184. Royer, S.; Duprez, D. Catalytic Oxidation of Carbon Monoxide over Transition Metal Oxides. Chem. Cat. Chem. 2011, 3, 24-65. [CrossRef]

185. Wang, H.; Mao, D.; Qi, J.; Zhang, Q.; Ma, X.; Song, S.; Gu, L.; Yu, R.; Wang, D. Hollow Multishelled Structure of Heterogeneous $\mathrm{Co}_{3} \mathrm{O}_{4}-\mathrm{CeO}_{2-x}$ Nanocomposite for CO Catalytic Oxidation. Adv. Funct. Mater. 2019, 29, 1-9. [CrossRef]

186. Van Spronsen, M.A.; Frenken, J.W.M.; Groot, I.M.N. Surface science under reaction conditions: CO oxidation on Pt and Pd model catalysts. Chem. Soc. Rev. 2017, 46, 4347-4374. [CrossRef]

187. Vogel, D.; Spiel, C.; Suchorski, Y.; Trinchero, A.; Schlögl, R.; Grönbeck, H.; Rupprechter, G. Local catalytic ignition during CO oxidation on low-index Pt and Pd surfaces: A combined PEEM, MS, and DFT study. Angew. Chem. Int. Ed. 2012, 51, 10041-10044. [CrossRef] [PubMed]

188. Slycke, J.T.; Mittemeijer, E.J.; Somers, M.A.J. Thermodynamics and Kinetics of Gas and Gas-Solid Reactions. In Themochemical Surface Engineering of Steels; Mittemeijer, E.J., Somers, M.A.J., Eds.; Woodhead Publishing Limited: Sawston, UK, 2015 ; pp. 3-11. ISBN 9780857095923.

189. Onn, T.M.; Monai, M.; Dai, S.; Fonda, E.; Montini, T.; Pan, X.; Graham, G.W.; Fornasiero, P.; Gorte, R.J. Smart Pd Catalyst with Improved Thermal Stability Supported on High-Surface-Area $\mathrm{LaFeO}_{3}$ Prepared by Atomic Layer Deposition. J. Am. Chem. Soc. 2018, 140, 4841-4848. [CrossRef] [PubMed]

190. Mao, X.; Foucher, A.C.; Montini, T.; Stach, E.A.; Fornasiero, P.; Gorte, R.J. Epitaxial and Strong Support Interactions between Pt and $\mathrm{LaFeO}_{3}$ Films Stabilize Pt Dispersion. J. Am. Chem. Soc. 2020, 142, 10373-10382. [CrossRef] [PubMed]

191. Montini, T.; Melchionna, M.; Monai, M.; Fornasiero, P. Fundamentals and Catalytic Applications of CeO2-Based Materials. Chem. Rev. 2016, 116, 5987-6041. [CrossRef]

192. Simchen, F.; Sieber, M.; Kopp, A.; Lampk, T. Introduction to Plasma Electrolytic Oxidation-An Overview of the Process and Applications. Coatings 2020, 10, 628. [CrossRef]

193. Jiang, Y.; Liu, B.; Yang, W.; Yang, L.; Li, S.; Liu, X.; Zhang, X.; Yang, R.; Jiang, X. Crystalline $\left(\mathrm{Ni}_{1-\mathrm{x}} \mathrm{Co}_{\mathrm{x}}\right)_{5} \mathrm{TiO}_{7}$ nanostructures grown in situ on a flexible metal substrate used towards efficient CO oxidation. Nanoscale 2017, 9, 11713-11719. [CrossRef]

194. Liu, X.; Wang, K.; Zhou, Y.; Tang, X.; Zhu, X.; Zhang, R.; Zhang, X.; Jiang, X.; Liu, B. In-situ fabrication of noble metal modified (Ce, $\mathrm{Zr}) \mathrm{O}_{2-\delta}$ monolithic catalysts for CO oxidation. Appl. Surf. Sci. 2019, 483, 721-729. [CrossRef]

195. Bashir, A.; Awan, T.I.; Tehseen, A.; Tahir, M.B.; Ijaz, M. Chemistry of Nanomaterials: Fundamentals and Applications, 1st ed.; Kindle Edition; Elsevier: Amsterdam, The Netherlands, 2020; ISBN 9780128189085.

196. Sivakumar, K.; Rossnagel, S.M. Deposition of aluminum-doped zinc oxide thin films for optical applications using rf and dc magnetron sputter deposition. J. Vac. Sci. Technol. A Vacuum Surf. Film. 2010, 28, 515-522. [CrossRef]

197. Lukiyanchuk, I.V.; Vasilyeva, M.S.; Sergeev, A.A.; Nepomnyashchii, A.V.; Serov, M.M.; Krit, B.L. Role and behavior of ultra-thin gold films on the fiber materials surface in the CO oxidation process. J. Alloys Compd. 2021, 852, 157042. [CrossRef]

198. Avila, P.; Montes, M.; Miró, E.E. Monolithic reactors for environmental applications: A review on preparation technologies. Chem. Eng. J. 2005, 109, 11-36. [CrossRef]

199. Bahlawane, N.; Rivera, E.F.; Kohse-Höinghaus, K.; Brechling, A.; Kleineberg, U. Characterization and tests of planar $\mathrm{Co}_{3} \mathrm{O}_{4}$ model catalysts prepared by chemical vapor deposition. Appl. Catal. B Environ. 2004, 53, 245-255. [CrossRef]

200. Moro-oka, Y.; Ozaki, A. Regularities in catalytic properties of metal oxides in propylene oxidation. J. Catal. $1966,5,116-124$. [CrossRef] 
201. Busca, G.; Finocchio, E.; Ramis, G.; Ricchiardi, G. On the role of acidity in catalytic oxidation. Catal. Today 1996, 32, 133-143. [CrossRef]

202. Stoian, M.; Lazar, L.; Uny, F.; Sanchette, F.; Fechete, I. Chemical vapour deposition (CVD) technique for abatement of volatile organic compounds (VOCs). Rev. Chim. 2020, 71, 97-113. [CrossRef]

203. Jansson, J.; Skoglundh, M.; Fridell, E.; Thormählen, P. A mechanistic study of low temperature CO oxidation over cobalt oxide. Top. Catal. 2001, 16-17, 385-389. [CrossRef]

204. Bahlawane, N. Kinetics of methane combustion over CVD-made cobalt oxide catalysts. Appl. Catal. B Environ. 2006, 67, 168-176. [CrossRef]

205. Moro-oka, Y.; Ueda, W.; Lee, K.H. The role of bulk oxide ion in the catalytic oxidation reaction over metal oxide catalyst. J. Mol. Catal. A Chem. 2003, 199, 139-148. [CrossRef]

206. Waqas, M.; El Kasmi, A.; Wang, Y.; Kouotou, P.M.; Tian, Z.Y. CVD synthesis of Cu-doped cobalt spinel thin film catalysts for kinetic study of propene oxidation. Colloids Surf. A Physicochem. Eng. Asp. 2018, 556, 195-200. [CrossRef]

207. Kansal, A. Sources and reactivity of NMHCs and VOCs in the atmosphere: A review. J. Hazard. Mater. 2009, 166, 17-26. [CrossRef] [PubMed]

208. Assebban, M.; Kasmi, A.E.L.; Harti, S.; Chafik, T. Intrinsic catalytic properties of extruded clay honeycomb monolith toward complete oxidation of air pollutants. J. Hazard. Mater. 2015, 300, 590-597. [CrossRef] [PubMed]

209. Kouotou, P.M.; Tian, Z.Y. Cobalt-iron oxides made by CVD for low temperature catalytic application. Phys. Status Solidi Appl. Mater. Sci. 2015, 212, 1508-1513. [CrossRef]

210. Tian, Z.Y.; Kouotou, P.M.; El Kasmi, A.; Ngamou, P.H.T.; Kohse-Höinghaus, K.; Vieker, H.; Beyer, A.; Gölzhäuser, A. Lowtemperature deep oxidation of olefins and DME over cobalt ferrite. Proc. Combust. Inst. 2015, 35, 2207-2214. [CrossRef]

211. Kouotou, P.M.; Vieker, H.; Tian, Z.Y.; Ngamou, P.T.; El Kasmi, A.; Beyer, A.; Gölzhäuser, A.; Kohse-Höinghaus, K. Structure-activity relation of spinel-type Co-Fe oxides for low-temperature CO oxidation. Catal. Sci. Technol. 2014, 4, 3359-3367. [CrossRef]

212. Törncrona, A.; Skoglundh, M.; Thormählen, P.; Fridell, E.; Jobson, E. Low temperature catalytic activity of cobalt oxide and ceria promoted Pt and Pd: -influence of pretreatment and gas composition. Appl. Catal. B Environ. 1997, 14, 131-145. [CrossRef]

213. Liu, H.; Cheung, P.; Iglesia, E. Zirconia-supported $\mathrm{MoO}_{\mathrm{x}}$ catalysts for the selective oxidation of dimethyl ether to formaldehyde: Structure, redox properties, and reaction pathways. J. Phys. Chem. B 2003, 107, 4118-4127. [CrossRef]

214. Waqas, M.; El Kasmi, A.; Wu, L.N.; Arshad, M.F.; Qin, W.; Tian, Z.Y. Catalytic combustion of CO over Cu-doped iron oxides: $\mathrm{CO}_{2}$ effects on activity. Fuel 2021, 289, 119760. [CrossRef]

215. Merino, N.A.; Barbero, B.P.; Eloy, P.; Cadús, L.E. $\mathrm{La}_{1-\mathrm{x}} \mathrm{Ca}_{\mathrm{x}} \mathrm{CoO}_{3}$ perovskite-type oxides: Identification of the surface oxygen species by XPS. Appl. Surf. Sci. 2006, 253, 1489-1493. [CrossRef]

216. Christensen, J.M.; Grunwaldt, J.D.; Jensen, A.D. Importance of the oxygen bond strength for catalytic activity in soot oxidation. Appl. Catal. B Environ. 2016, 188, 235-244. [CrossRef]

217. Liu, Y.; Zhao, Y.; Yu, Y.; Ahmad, M.; Sun, H. Facile synthesis of single-crystal mesoporous $\mathrm{CoNiO}_{2}$ nanosheets assembled flowers as anode materials for lithium-ion batteries. Electrochim. Acta 2014, 132, 404-409. [CrossRef]

218. Waqas, M.; Kouotou, P.M.; El Kasmi, A.; Wang, Y.; Tian, Z.Y. Role of copper grid mesh in the catalytic oxidation of CO over one-step synthesized Cu-Fe-Co ternary oxides thin film. Chin. Chem. Lett. 2020, 31, 1201-1206. [CrossRef]

219. Kouotou, P.M.; Tian, Z.Y. Controlled synthesis of $\alpha-\mathrm{Fe}_{2} \mathrm{O}_{3} @ \mathrm{Fe}_{3} \mathrm{O}_{4}$ composite catalysts for exhaust gas purification. Proc. Combust. Inst. 2019, 37, 5445-5453. [CrossRef]

220. Tian, Z.Y.; Kouotou, P.M.; Bahlawane, N.; Ngamou, P.T. Synthesis of the catalytically active $\mathrm{Mn}_{3} \mathrm{O}_{4}$ spinel and its thermal properties. J. Phys. Chem. C 2013, 117, 6218-6224. [CrossRef] 